Niğde Ömer Halisdemir Üniversitesi Mühendislik Bilimleri Dergisi
Niğde Ömer Halisdemir University Journal of Engineering Sciences

\title{
Covid-19 ile mücadelede bitkilerin olası rolü
}

\section{The possible role of plants in combating Covid-19}

\author{
Begüm Güler $^{1 *(D)}$, Meltem Bayraktar ${ }^{2}$ (D) Aynur Gürel ${ }^{3}$ (i) \\ ${ }^{I}$ Ege Üniversitesi Fen Bilimleri Enstitüsü, Biyomühendislik Anabilim Dall, 35040, İzmir Türkiye \\ ${ }^{2}$ Kırşehir Ahi Evran Üniversitesi, Mühendislik-Mimarlık Fakültesi, Genetik ve Biyomühendislik Bölümü, 40100, Kırşehir, Türkiye \\ ${ }^{3}$ Ege Üniversitesi, Mühendislik Fakültesi, Biyomühendislik Bölümü, 35040, İzmir Türkiye
}

\begin{abstract}
Özet
2019 yılının sonlarına doğru Çin'in Wuhan eyaletinde başlayan ve hızla yayılan Covid-19 pandemisi ile tüm dünyada yaşam durma noktasına gelmiş çok sayıda insan hayatını kaybetmiştir. Varolan kriz araştırmacıları süratli çözüm bulmaya yönlendirmiş ve farklı araştırma konularında çalışmalara başlanmıştır. SARS ve MERS salgınları sırasında kullanılan tedavi yöntemleri hastaların iyileştirilmesinde yetersiz kalmış ve tam etkili protokollerin geliştirilmesi amacıyla farklı kaynaklar araştırılmaya başlanmıştır. Bu kaynaklardan birisi olan bitkiler, farklı biyoteknolojik yollar aracılığıyla aşı üretiminde kullanılabilecekleri gibi, sahip oldukları sekonder metabolitler nedeniyle tedavi amaçlı olarak da değerlendirilmektedir. Bitkilerin çeşitli viral hastalıkların tedavisinde daha önceki salgınlarda da kullanıldığı, güvenli, hızlı ve etkili bir çözüm yolu sunabildikleri gösterilmiştir. Bitkilerin aşı ve antiviral proteinlerin üretimleri için biyoreaktör olarak kullanımları, kitlesel üretimlere izin verecek nitelikte ucuz bir tekniktir. Bitkiler sahip oldukları sekonder metabolitlerin gösterdikleri antiviral etki ile virüslerle mücadelede etkili araçlar olarak kabul edilebilirler. Gerçekleştirilen bu derlemede tüm dünyada kitlesel bir sağlık krizine neden olan SARS-CoV2 virüsü ile ilgili genel bilgiler verildikten sonra, viral salgınlarda aşı üretim yöntemleri, bitkilerden elde edilen aşılar, yenebilir aşıların Covid-19 aşısı olarak kullanım potansiyelleri ve bitki sekonder metabolitlerinin antiviral etkilerinin salgının kontrolündeki rolleri üzerine bilgiler özetlenmiştir.
\end{abstract}

Anahtar kelimeler: Koronavirüs, Covid-19, Bitkiler, Aş1, Sekonder metabolit

\section{Giriş}

Covid-19 pandemisi, 2019 yılının sonlarına doğru başlayan ve ilerleyen dönemde tüm dünyayı saran en önemli sağlık krizlerinden biridir. Salgın; sağlık sektörünün yanı sıra, ekonomik piyasalarda ve sosyal yaşamda da ciddi krizlere yol açmıştır [1, 2]. Dünya Sağlık Örgütü (DSÖ), Covid-19'u yüksek bulaşma oranı ve belirli aşıların ya da tedavi edecek ilaçların bulunmaması nedeniyle, bir pandemi olarak ilan etmiştir [3, 4]. Özellikle bulaşıcılık potansiyelinin yüksek olmasından dolayı, hastanelerdeki yoğunluklar ciddi oranlara ulaşmış ve tüm dünyadaki bilim insanları çözüm

\begin{abstract}
With the Covid-19 pandemic that started in Wuhan province of China towards the end of 2019 and spread rapidly, many people around the world lost their lives. Existing crisis has led researchers to find solutions quickly and studies on different research topics have been initiated. The treatment methods used during the SARS and MERS epidemics were insufficient in treatment of patients, and different resources have been sought in order to develop a fully effective protocols. Plants, one of these sources, can be used in vaccine production through different biotechnological ways, and secondary metabolites of plants can also be evaluated for therapeutic purposes. It has been shown that plants have been used in the treatment of various viral diseases in previous epidemics and that they can offer a safe, fast and effective solution. The use of plants as bioreactors for the production of vaccine and antiviral proteins is an inexpensive technique that allows mass production. Plants are regarded as effective means of combating viruses with the antiviral effect of their secondary metabolites. In this review, after giving general information about the SARS-CoV-2 virus, which causes a massive health crisis all over the world, information about vaccine production methods in viral epidemics, vaccines which obtained from plants, potential use of edible vaccines as Covid-19 vaccine and roles of antiviral effects of plant secondary metabolites in the control of the epidemic are summarized.
\end{abstract}

Keywords: Coronavirus, Covid-19, Plants, Vaccine, Secondary metabolite

üretmek üzere kolları sıvamışlardır. Çalışmalar; genel olarak taşıyıcıların hızlı tespitinin sağlanması, hastaların tedavisine yönelik uygun antiviral ilaçların üretilmesi ve popülasyonun maruz kalmayan kısmını korumak için uygun aşının geliştirilmesi üzerine odaklanmıştır [5]. Bu süreç içerisinde de dünya genelinde hükümetler, sosyal teması azaltmak adına ülke çapında karantina uygulamalarına gitmiş, bir araya gelişler azaltılmaya çalışılmış ve maske takmak teşvik edilmiştir. Hijyen kuralları kapsamında alınan bu önlemler ile kısmi de olsa yayılma yavaşlatılmıştır [6].

Virüs hakkında; bulaşma şekli, morfolojisi ve diğer ayrıntılı bilgiler hızla ortaya çıkarken, DSÖ ve dünyanın

\footnotetext{
* Sorumlu yazar / Corresponding author, e-posta / e-mail: begumakyol.ege@ gmail.com (B.Güler) Geliş / Recieved 09.04.2021 Kabul / Accepted: 22.06.2021 Yayımlanma / Published: 27.07.2021 doi: $10.28948 /$ ngmuh.912506
} 
önde gelen kuruluşları acil durum ve kontrol önlemleri açısından dünyanın dört bir yanındaki ülkelere tavsiyelerde bulunmuşlar ve küresel ölçekte alınan önlemler ile yayılma yavaşlatılarak, virüsün kontrol altına alınması konusunda daha verimli çalışmalar gerçekleştirilmiş̧ir [7]. Ancak hızlı tanı kitleri, aşı ve terapötiklerin üretimindeki en kritik nokta, bu ürünlerin dağıtımı, uygulanabilirliği ve erişilebilirliği konusunda dünyanın her yerinde insanların eşit haklara sahip olmasidır [2].

Mevcut durumda hastaların tedavisinde kullanılan seçenekler semptomları azaltmakla birlikte, farklı ilaç ve aşıların geliştirilmesi ile ilgili çalışmalar yoğun şekilde devam etmektedir. Bu noktada en büyük korkulardan birisi kullanılacak yöntemlerin güvenilirliğidir [2, 7]. Tıbbi bitkiler, Covid-19'a karși yan etkisi olmayan veya çok az yan etkiye sahip terapötik ilaçlar geliştirmek için kullanılabilecek nitelikte biyoaktif bileşiklere sahiptirler [4]. Tıbbi bitkiler, sekonder metabolizma ürünleri olan bu biyoaktif bileșikler ile büyük bir pazar oluștururlar. Ancak iklime ve coğrafik koșullara bağlı olma durumunun neden olduğu kısıtlar, gelişen bitki biyoteknolojisi uygulamalarının katkısı ile bitkilerin hücre fabrikası olarak kullanımlarıla aşılabilmektedir. Bitki biyoteknolojisi koronavirüse karşı ilaç üretiminde uniform, kullanımı güvenli ve yüksek verimli bir platform sunmaktadır [2, 7].

Bitki doku kültürü uygulamaları, tıbbi açıdan önemli sekonder metabolitlerin üretiminde bitki mekanizmasının en etkili şekilde kullanımını sağlayan bitki biyoteknolojisinin temel direğidir. Bitkilerin ex vitro koşullarda yetiștirilmesinin zaman alması, biyoaktif bileșiklerin ekstraksiyonu ve izolasyonunun pahalı olması vb. nedenlerden dolayı; hücre süspansiyon kültürleri, kallus kültürleri, saçaklı kök kültürleri, adventif kök kültürleri ve diğer organ kültürleri gibi çeșitli doku kültürü teknikleri Covid-19 tedavisi için bitkisel metabolitlerin daha kısa sürede, uniform ve büyük çaplı üretimi açısından iyi bir alternatif olarak görülmektedir. Doku kültürü yöntemlerinin çevresel kısıtlamalar olmadan doğal bileşiklerin sürekli ve güvenilir bir şekilde üretimi gibi önemli avantajları söz konusudur $[7,8]$.

\section{Virüs hakkında genel bilgiler}

Koronavirüsler; büyük, küre şekilli ve yaklaşık $125 \mathrm{~nm}$ yarıçapında tek zincirli RNA virüsleridirler. Genomik RNA's1, tüm RNA virüsleri içerisinde en uzun olanıdır (yaklaşık olarak 26.2-31.7 kb) [9]. Özellikle üst solunum yolu enfeksiyonlarına sebep olan koronavirüs $(\mathrm{CoV})$, genetik materyali tek zincirli RNA olan zarflı virüs grubu olarak tanımlanmaktadır [10]. Yaklaşı 30kb uzunluğundadır. Spike (S), nüklokapsit (N), zarf (E) ve membran proteini (M) olmak üzere dört yapısal proteinden oluşmaktadır $[3,11]$. $\mathrm{Bu}$ proteinler, çift lipit katmanlı ve bombeli protein kilıf üzerinde S:E:M oranı 20:1:300 olacak şekilde yerleşmiştir. Bir koronavirüs partikülü yüzeyinde ortalama 74 adet $S$ proteini bulundurmaktadır [9].

Koronavirüsler ilk olarak 1960'larda tanımlanmıs, bu gruba ait farklı virüsler toplumlarda ölümlere neden olan virüs türleri olmuşlardır [10]. Virüsler bu isimlerini, latince taç anlamına gelen "corona" kelimesine benzeyen yuvarlak güneş tacı yapısından almaktadır [12]. Betakoronavirüs cinsinin yeni bir üyesi olan Coronaviridae ailesine ait koronavirüs (2019-nCoV/SARS-CoV-2), SARS-CoV (Severe Acute Respiratory Syndrome-Ağır Akut Solunum Yolu Yetmezliği Sendromu) ile yakından ilişkilidir ve $\% 70$ benzerlik göstermektedir [4, 13]. İki virüs arasındaki farklı olan 308 aminoasitin genomik analizi tamamlanmış ve fonksiyonel ve patojenik ayrışmanın incelenmesinde bu farklılık başlangıç noktası olmuştur [13]. SARS-CoV-2'nin sahip olduğu RNA, protein translasyonu sirasında mRNA gibi davranmaktadır [14].

SARS-CoV; ilk olarak 2003 yılının Şubat ayında Çin'de görülmeye başlamış, 5 kıta ve 32 ülkede \%10-15'lik ölüm oranı ile 916 kişinin hayatını kaybetmesine sebep olmuş ilk koronavirüs enfeksiyonudur. Yaklaşık on y1l kadar sonra Suudi Arabistan'dan başlayarak diğer Orta Doğu ülkelerine yayılan MERS-CoV (Middle East Respiratory SyndromeOrta Doğu Solunum Sendromu) ise 2018 yılına kadar devam etmiş ve \%39'luk ölüm oranı ile 543 kişinin ölümüne neden olmuştur. İlk vaka örneği 30 Aralık 2019 yılında Çin'in Wuhan kentinde bildirilen yeni koronavirüs ise ilk olarak 2019-nCoV (SARS-CoV-2) olarak adlandırılmıştır [15]. 10 Ocak 2020'de RT-PCR yöntemleri aracılığı ile ilk tam genom dizisi piyasaya sürülmüştür [16]. 12 Şubat 2020 tarihinde ise DSÖ bu patojeni 2019 yeni koronavirüs (2019nCoV), COVID-19 veya Covid-19 olarak adlandırmıştır [4, 15]. 11 Mart 2020 tarihinde DSÖ tüm dünyada pandemi ilan etmiştir. $\mathrm{Bu}$ pandemi, 1918 influenza salgınından beridir kayıtlara geçen beşinci pandemidir [17]. 20 Haziran 2021 tarihinde ise yaklaşık olarak 178 milyon kişi virüsten etkilenmiş, 3.86 milyondan fazla kiși de yaşamını yitirmiştir.

Virüs-konukçu ilişkisindeki en etkili faktör, virüsün hücreye giriş ve konukçu içerisindeki replikasyonudur. Koronavirüsler, genellikle insan epitelyal hücrelerini hedef almaktadırlar [9]. Hedef hücreye girișten $S$ proteini sorumludur [18]. S proteini ise S1 alt birimi (685 aminoasit) ve S2 alt birimi (588 aminoasit) olmak üzere iki alt birime sahiptir. S2, koronavirüsler arasında genellikle korunan bölgedir (\%99). S1 ise \%70 benzerlik göstermekle birlikte, reseptör bağlanma domaini (RBD) ile virüs girişi ve konukçu hücre tropizmi arasındaki farklılıklardan sorumludur [1]. Virüsün insan hücrelerine girişi, viral protein S'nin S1 alt biriminin insan hücre zarı üzerinde bulunan Anjiyotensin Dönüștürücü Enzim 2 (Angiotensin Converting Enzyme 2: ACE2) olarak adlandırılan reseptör proteinlerine bağlanmasıyla meydana gelmektedir [19]. SARS-CoV-2 de SARS-CoV ile benzer şekilde virüs üzerindeki reseptör bağlayıcı domain ACE-2 ile bağlanmaktadır. Ancak SARSCoV-2'nin reseptör proteine afinitesi, SARS-CoV'un yaklaşık 20 katı kadardır. Bu sebeple ACE-2, Covid-19 enfeksiyonunda terapötik olarak kullanılabilme potansiyeline sahiptir $[11,20]$. SARS-CoV-2/COVID-19 ile enfekte olmuş bir kişinin öksürük veya hapşırma sonucu oluşturduğu damlacıklara yakın temas nedeniyle maruz kalan insanlar, bu virüsle kolayca enfekte olmaktadırlar [4]. Virüs ayrıca kontamine yüzey/objelerle veya el/yüz/ağız ile temas yoluyla dolaylı olarak da bulaşabilmektedir [14]. Yapılan araştırmalar göstermiştir ki, enfekte olmuş bireyler yüksek oranlarda SARS-CoV-2 S1 RBD spesifik IgG 
antikorları göstermekle birlikte, bunun çok düşük bir oranı (26 hastadan 3'ü) SARS-CoV-2'nin ACE-2 reseptörüne bağlanmasını durdurabilmiștir [1].

Çeşitli interferon uygulamaları, monoklonal antikorlar, oligonükleotit bazlı tedaviler, peptitler, küçük moleküllü ilaçlar ve aşılarla ilgili çalışmalar devam etmesine rağmen, salgının önlenmesinde ilk hat savunmasını var olan ilaçların kullanımı oluşturmaktadır [21]. Halen Remdesivir, Hidroksiklorokin, Lopinavir / Ritonavir gibi ilaçlar ve diğer HIV proteaz inhibitörleri hastaların tedavisinde kullanılmaktadır [4]. Remdesivir; geniş yelpazede RNA virüs enfeksiyonları (SARS ve MERS koronavirüsleri dahil) için kullanılan önemli bir antiviral ilaçtır. Yapılan çalışmalarda, SARS-CoV-2'nin hücreye girişi sonrasında nükleotit analoğu olarak görev alarak antiviral etki gösterdiğ ispatlanmıştır. Remdevisirin etkisinin belirlenmesi amacıyla yapılan çalışmalarda \%68'lik bir iyileşme olduğu tespit edilmesine rağmen, çalışmada kontrol grubunun kullanılmamış olması büyük eksiklik olarak görüşmüştür. DSÖ ise Remdevisir kullanımının hastalarda sağkalım ve iyileşme oranlarını arttırdığına dair yeterli kanıt olmadığını öne sürerek, hastalığın ciddiyetine bakılmaksızın hastanede yatan bireylerde Remdesivir kullanımını kısıtlayan şartlı bir tavsiye yayınlamıştır. Ritonavir interferonu, Lopinavir klasik ilacı ve kortikosteroid (3-5 gün) ile gerçekleştirilen bir çalışmada [22]; 51 hastadan 50'sinin iyileştiği belirlenirken, yapılan başka bir araştırmada [23] ise 26 yoğun bakım hastasının 16'sının taburcu olduğu bildirilmiştir. Ancak benzer şekilde Lopinavir/Ritonavir kullanan 199 Covid-19 hastası ile standart tedavi gören grup arasında belirgin farklılığın görülmemesi, bu konudaki araştırmaların devam etmesi gerektiğini göstermiştir [10]. Bunlar dışında plazma terapileri de etkili sonuçlar vermiştir. Ancak tüm bu sentetik ilaçların kullanımının gösterdiği ciddi yan etkiler; araştırmacıları güvenli, etkili ve ucuz olmasının yanı sıra; en az yan etki gösteren yeni ilaç ve aşıları araştırmaya yönlendirmiştir [21].

\section{Viral salgınlarda aşı üretim tekniklerine genel bakış}

DSÖ’nün verilerine göre her yıl yaklaşık 780,000 kişi hayatını kaybetmektedir. Var olan Covid-19 ise popülasyonlar üzerinde ciddi bir soruna yol açmış ve aşılamanın önemini artırmıştır [24]. Geçmiş yıllarda yaşanan viral salgınlar göstermiştir ki, salgınla mücadelede en etkili çözüm hızlı tespit ve hızlı aşılama ile sağlanmaktadır. Aşı üretim proseslerinde ya da yöntemlerinde geçmiş yıllarda görülen aksaklıklar günümüzde var olan pandemide düzeltilmeye çalışılmıştır. Örneğin, 2009 yılında yaşanan influenza A (H1N1) salgını sırasında aşı üretimi amacıyla kullanılan yumurta-bazlı üretim teknikleri yavaş kalmış ve aşının paylaşımı ve dağıtımında yaşanan sorunlar sebebiyle ilk dalganın atlatılmasında başarısız olunmuştur. Ya da aşı üretimlerinde kullanılan MDCK (Madin-Darby Canine Kidney) ve EHE hücre hatları, SARS-CoV-1 ve SARS-CoV2 virüslerinin replikasyonuna izin vermediği için Covid-19 pandemisinde kullanılamamışlardır [25]. Ayrıca inaktif aşıların kullanımının ise zayıf immun yanıta sebep olduğu belirlenmiştir [24]. Bu eksiklikler, aşının doğal viral amplifikasyonuna güven sorununun oluşmasına neden olmuş, bunun yerine viral yapısal proteinler ve/veya membran elementlerini içeren rekombinant viral peptitleri veya virüs benzeri partikülleri (Virus-like particles-VLPs) kullanan yeni jenerasyon aşılara verilen önemi artırmıştır. VLP'ler genel olarak viral partiküllerle yapısal olarak benzerlik göstermekle birlikte, çoğalmak için gereken genetik materyalden yoksundurlar. Çoğalmak için de doğal virüsün bulaşıcılığına ihtiyaç duymadıklarından daha geniş bir konukçu seçeneğine sahiptirler. Böcek hücre hatları ve bitkiler de bu hatlara dahildirler. Canlı hücre içermemesi sebebiyle bu üretim tekniği; daha güvenli olmasının yanı sıra, konukçu çeşitliliğinin de bulunması ölçeklenebilmesinde çok önemli avantajlar sağlamaktadır [25].

Biyomühendislik teknolojileri ile aşı üretiminde viral antijenler olarak VLP'lerin kullanımının çok sayıda avantajları bulunmaktadır. Antijenlerin sunucu hücre tarafından kolaylıkla alınmaları, adaptif bağışıklığı aktive etmeleri, güçlü hücresel ve hormonal bağışıklığı sağlamaları bu avantajlardan bazılarıdır. Bitkilerin VLP üretimi için kullanımı ise kitlesel üretimlere imkan sağlamaları nedeniyle, araştırmacılar tarafından sıklıkla tercih edilen bir teknik olmaktadır. Medicago şirketi, bir aylık bir zamanda tütün hücrelerini kullanarak 10 milyon doz H1N1 influenza aşısının üretimini gerçekleştirmişlerdir [1].

Bitkiler, VLP'ler ya da aşılar gibi çok sayıda biyolojik prosesin yürütülmesinde biyoreaktör görevi görebilme potansiyeline sahiptirler. Bitkilerin yabancı genler kullanılarak transformasyonu ile ilaçların, aşıların ve antikorların farklı insan patojenlerine karşı kullanımı gerçekleştirilmekte ve bu şekilde güvenli, depolama sorunu olmayan bir üretim şekli geliştirilebilmektedir. Gerçekleştirilen birçok araştırma ve klinik çalışma, bitkisel kökenli aşıların etkili ve güvenli olduğunu göstermiştir. Kolera, Dang humması virüsü, Hepatit B virüsü, HIV ve Ebola'ya karş1 monoklonal antikorlar ve Gaucher hastalığının tedavisinde kullanılan glukoserebrosidaz, bitkilerden elde edilen aşı ve terapötiklere birer örnektir [10].

Covid-19'un tedavisinde kullanmak amaciyla üretilmiş farklı aşı ve antikorlar mevcut olmasına rağmen, hiçbiri hakkında kesin bir kanıya varılamamaktadır [10]. Ayrıca virüslerin, uygulanan ilaçlara karşı direnç kazanmak amacıyla sahip oldukları genetik materyali mutasyona uğratma yeteneklerinden dolayı, geniş spektrumlu bir antiviral tedavinin geliştirilmesi son derece zor bir prosestir. Sentetik olarak geliştirilen antiviral ilaçların uygulamasının zaman zaman beklemeyen yan etkileri ciddi sağlık sorunlarına da yol açmaktadır. Bu sebeple bitkisel kökenli tedaviler, yan etkileri en aza indirerek antiviral tedavilerin geliştirilmesinde yeni firsatlar sunmaktadır [9].

\section{Bitkilerden rekombinant protein üretimleri ve covid- 19 ile mücadele}

Bitkilerden önemli proteinlerin üretim teknikleri ve bu proteinlerin endüstriyel olarak kullanımları son yıllarda önemli çalışma konularından olmuştur. Farklı kültür teknikleri ve transgenik bitkilerin kullanımı ile yabancı proteinlerin üretimi gerçekleştirilebilmektedir [26]. Sunduğu ekonomik potansiyel ile transgenik bitkilerin farmasötik 
(ilaç üretiminde kullanılan) ve terapötik (tedavide kullanılan) proteinlerin üretimlerinde kullanımları, giderek artan önemli uygulama alanlarına yol açmıştır [27]. Bitkilerden elde edilen aşıların ve antikorların hastalıkların tedavisinde kullanımı oldukça güvenlidir ve ayrıca virüs veya bakteriyal toksinlerin incelenmesini gerektirmediği için maliyetlerin düşürülmesini sağlar [28].

"Moleküler çiftçilik" adı altında bitkiler, rekombinant aşı ve ilaçların üretiminde 30 yıldan uzun süredir kullanılmaktadır [10]. İlk olarak 1980'li yıllarda ilk rekombinant antikorların başarılı üretimi gerçekleştirilmiştir. Bu tarihten itibaren çok sayıda protein, bitkiler aracılığıyla üretilmiş ve ticarileştirilmiştir [2]. Son yıllarda, gelişen genetik mühendisliği teknikleri ile birlikte antikor, viral ve bakteriyal antijen, hayvan ve insan terapötik proteinleri gibi çeşitli rekombinant proteinlerin üretimleri hız kazanarak artmaktadır. Bitkisel sistemlerden transgenik bitki teknolojileri kullanılarak, antikor ve yenebilir aşılar, peptit, protein ve enzim gibi önemli farmasötiklerin üretimi, diğer üretim sistemlerine göre biyolojik ya da ekonomik olarak daha avantajlıdır [29].

Bitki doku kültürü ile ilk rekombinant proteinin üretimi 90'lı yılların başında gerçekleşmiştir. Bunun arkasından transgenik hücre süspansiyon kültürleri çeltik, soya fasulyesi ve domates gibi bitkilerde protein üretimleri için kullanılmıştır [26]. 1997 yılında, transgenik misır kullanılarak ticari rekombinant avidin üretimi büyük ölçekte gerçekleştirilmiştir [30]. Bitki sistemlerinde rekombinant protein üretimi gerçekleştikten sonra saflaştırma işlemine ihtiyaç duyulduğundan, üretimin ticarileşmesi için, toplam çözünmüş protein (TSP: Total Soluble Protein) miktarının \%1 oranına yaklaşması gerekir. Rekombinant proteinlerin üretimini etkileyen faktörler; konukçu bitkinin üretim potansiyeli ve ekspresyon sistemi, transgenin ekspresyon seviyesi ve rekombinant genin stabilitesidir [27].

Bitkilerin biyoreaktör olarak kullanımları; rekombinant proteinlerin yüksek konsantrasyonda düşük maliyetle üretimlerini sağlamaktadır. Buna ek olarak tohumlarda formüle edilen enzimlerin uzun süreli kararlı oldukları, depolama ve taşınım masraflarının da azaltılmasını sağladıkları da bilinmektedir. Daha önemlisi üretim miktarı esnek olabilmekte ve pazar sunuş formu kolaylıkla değiștirilebilmektedir [28]. Dikkat edilmesi gereken önemli nokta; doğal antikorlar ile rekombinant hayvan ve insan hücrelerinde üretilen ve bitkilerden elde edilen antikorlar arasında aktiflik ve spesifiklik açısından farklılıkların bulunmasıdır [27].

ABD Savunma İleri Araştırma Projeleri Ajansı (The Defense Advanced Research Projects Agency-DARPA) tarafindan desteklenen Blue Angel Projesi kapsamında, bitki bazlı sistemlerin aşı üretim potansiyellerine dikkat çekilerek; "yeni türlerin neden olduğu pandemilere ve ayrıca kasıtlı biyolojik tehditlerin neden olduğu enfeksiyonlara karşı aşı sağlama konusunda yetersiz kapasite" konusu ele alınmaya çalışılmış ve üç temel kriter belirlenmiştir. Bu kriterlerden ilki; yüksek muhafaza oranına sahip, kendi kendine yeterli bitki bazlı farmasötik üretim tesisi geliştirmektir. İkincisi; bir tesis inşa etmek ve işletmeye almak, bir aday protein antijeni geliştirmek ve ticari ölçekte bir hedef protein sunarak işlem sağlamlığını göstermektir ve sonuncusu ise; bu üretim prosesini 18 aydan daha kısa bir zaman aralığında tamamlamaktır [31]. Bu proje; bitki bazlı aşı üretim sistemlerinin hızlı aşı üretimine imkan verdiğini ve beklenmedik bir viral salgını bastırmak için gerekli olan üretim hızına sahip olduğunu göstermiştir. Medicago Inc., Caliber Biotherapeutics Inc. (iBio Inc. yeni ad1), Fraunhofer CMB ve Kentucky BioProcessing Inc. şirketleri bunu başarı ile gerçekleştirmiş bazı şirketlerdir. Bu şirketler özellikle kanser terapilerinde kullanılan çeşitli aşı ve/veya antikorları ürün listelerinde bulundurmaktadır. Medicago şirketi, yeni bir grip aşısının büyük miktarda üretim ve teslimini 3 aylık bir sürede gerçekleştirebileceğini bildirmiştir. 2014 yılında Kentucky Bioprocessing, "Zmapp” adlı insan kullanımı için acil durum onayı almış Ebola antikor kokteylinin üretimini hızlıca gerçekleştirmiş ve Mapp Biopharmaceutical aracılığı ile dağıtımını sağlamıştır. Bu durum, bitki bazlı üretim sistemlerinin aşı üretimininde kullanımın hızını gösteren bir olay olmuştur. Yakın zamanda ise, Medicago şirketi COVID-19 S protein sekansına ulaştıktan 20 gün sonra VLP aş1 üyesini üretmeyi başarmıştır [25].

İmmun yanıtın gerçekleşmesinde önemli rol oynayan antikorların bitkilerde başarılı şekilde ekspresyonlarının gerçekleştirilmesi ile yeni buluşların önü açılmıştır. Tütün bitkisinde ilk kez immunoglobulin fragmentlerinin sentezinin gerçekleştirilmesinin ardından, birçok bitkide benzer çalışma gerçekleştirilmiş ve "plantibody" olarak adlandırılmışlardır. İzolasyon ve saflaştırma işlemlerinin ardından elde edilen ajanlar immunokromatografi ya da medikal uygulamalarda kullanılabilmektedir [32].

Bitki hücreleri, ağızdan alınan aşıların üretimi için son derece uygun platformlardır. Bu platformlar "yenebilir aşı" olarak da adlandırılmaktadır [14]. Bitkilerde antijen determinantlarının eksprese edilmesiyle ilgili ilk teknolojiler; yenebilir aşıların üretimi üzerine yoğunlaşmış olsa da, sonraki dönemlerde yeterli dozlar üzerine araştırmalar gerçekleştirilmiş ve yenebilir aşılar yerini "bitki aşıları" na bırakmıştır. Aşının uygun dozunun belirlenmesi amaciyla, tohumların, dondurularak kurutulmuş meyveler ya da yaprakların toz haline getirilmiş formları, maliyet düşürülerek kullanılmıştır. Toz halindeki bitkisel materyalin büyük ölçekte üretimi ile uygun aşı dozunun miktarının belirlenmesine yönelik çalışmalar kolaylıkla gerçekleştirilmekte ve kalite kontrol sağlanabilmektedir. Ayrıca bu materyal etkisini arttırmak amaciyla mukozal adjuvanlar, vitaminler ya da farklı aşılarla birlikte uygulanabilmektedir. Bugüne kadar üretilmiş çok sayıda antijenik determinant bulunmaktadır [32].

Protein ekspresyonlarının bitkide gerçekleştiği kısımlar uzun yıllardır araştırmacıların çalışma konularından olmuştur. Tohumlarda (mısır, kanola, soya fasulyesi, çeltik), yapraklarda (tütün, yonca, marul), su bitkilerinde (Lemna minor), bitki hücre kültürlerinde (tütün, havuç, çeltik) ve saçaklı kök kültürlerinde protein ekspresyonlarının gerçekleştirilmesine yönelik çalışmalar yapılmıştır. $\mathrm{Bu}$ üretimlerin üç başlık altında toparlanması mümkündür. $\mathrm{Bu}$ başlıklar; tam bitki stabil ekspresyon sistemleri, tam bitki geçici ekspresyon sistemleri ve in vitro kültür sistemleri olarak adlandırılabilmektedir (Şekil 1) [33]. Tütün, turp, 
patates ve domates gibi pek çok bitki aşı üretimi amacıyla kullanılmıştır. Turpta üretilen interferon alfa, tütün ve patateste üretilen insan serum albumini, tütünde hepatit $\mathrm{B}$ virüsüne karşı üretilen antikorlar ( $\mathrm{scFv} \mathrm{mAb})$ bunun bazı örnekleridir. Transgenik ayçiçeğinden üretilen insülin (SemBioSys), transgenik arpadan elde edilen büyüme faktörü, transgenik havuçtan üretilen ve Gaucher hastalığının tedavisinde kullanılan taligluseraz enzimi (ProtalixBio Therapeutics), transgenik tütünden elde edilen kuş gribi aşısı (Medicago) ve transgenik tütünden üretilen Ebola aşısı (Mapp Biopharmaceutical) ticari olarak üretimi yapılan bitkisel temelli biyofarmasötik ürünlerdir [1].

Bitki bazlı aşılar, üçüncü jenerasyon aşılar olarak adlandırılmaktadır. Bu aşı üretim tekniği, bitki ekspresyon sisteminde aşının klonlanması ile antijenik ya da koruyucu özellikteki proteinin bitki içerisinde üretilmesi esasına dayanmaktadır. Bu şekilde aşılar; bitkiler biyoreaktör olarak kullanılarak üretilmekte, çok sayıda üretim aynı anda gerçekleştirilebilmekte ve sürekli üretim sağlanabilmektedir [1]. Transgenik bitki aşılarının üretimi için iki farklı yol vardır. Bunlardan birincisi, yabancı proteinin bitki doku kültürü teknikleri ile üretimi ve ayırma saflaştırma işlemlerinin gerçekleştirilerek damar içi kullanımlar için yüksek kalitede ürün elde edilmesi yöntemidir. Diğer yöntem ise, alt akım işlemine gerek kalmadan oral kullanım için uygun proteinin sindirilebilir kısmının ekspresyonuna dayanmaktadır. Bugüne kadar yapılan çalışmalarda 5 grup bitki aşısı belirlenmiştir: bakteriyel aşılar, virüs aşıları, gebelik aşıları, parazit aşıları ve diabet aşıları (Tablo 1). Transgenik bitkilerden aşıların elde edilmesine yönelik çalışmalar hızlı şekilde gelişme göstermesine rağmen, ticarileşme aşamasına geçmeden önce çözülmesi gereken birkaç sorun bulunmaktadır. Bunlardan birisi ölçek büyütmede model bitki olarak Arabidopsis thaliana ve Nicotiana tabacum L. gibi sindirimi zor olan bitkilerin kullanılmasıdır. Tütünde aşıların üretilmesi, nikotin ve diğer alkaloitlerin kontaminasyon riskini barındırmaktadır [27].

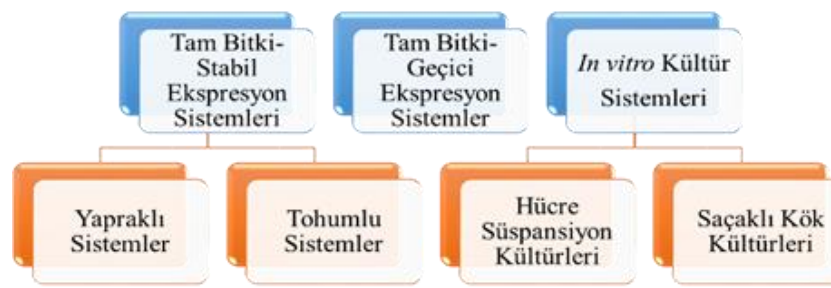

Şekil 1. Bitki ekspresyon sistemlerinin gruplandırılması [34].

Yapılan araştırmalarda görülmüştür ki; bitkilerin rekombinant proteinlerin üretiminde konukçu olarak kullanımının maliyeti, memeli hücrelerinin kullanıldığ sistemlerin \%0.1'i, bakteri ekspresyon sistemlerinin ise $\% 2$ 10’u kadardır [11]. Transgenik bitkiler kullanılarak aşıların üretimi, memeli patojenleri ile kontaminasyon riskini azaltmasının yanı sıra, oral kullanımın gerçekleştirilmesine de izin vermesi gibi birçok sebeple son yıllarda önemli araştırma alanlarından biri olmuştur [2, 35].

Yenebilir aşı; patojenlere ait antijenleri üreten transgenik bitkilerin tüketilmesiyle insan ve hayvanlarda çeşitli bulaşıcı hastalıklara karşı bağışıklık proteinlerinin oluşumuna yol açan aşılardır. Yenebilir aşılar, seçili bir genin bitkiye aktarıldığı ve bu genin kodladığı proteinin (antijen) üretiminin gerçekleştirildiği sub-unit aşılardır [35]. Yenebilir aşılar;

- Düşük maliyet,

- Hizlı ölçek büyütme,

- $\quad$ Aynı anda çoklu aşıların üretimine olanak vermesi,

- Uygun koşullarda uzun süreli depolama,

- Üretim sirasında sterilizasyonun bir problem olmamas1,

- Transportu sırasında soğuk zincir gereksiniminin azalmas1,

- Aşı örneklerinde karşılaşılan kontaminasyon risklerinin ortadan kalkması,

- $\quad$ İğne ve şırınga maliyetlerinin ortadan kalması,

- Uygulama sirasında gerekli olan tıbbi yardım ihtiyacının azalması,

- Çocuklarda görülen enjeksiyon korkusunun ortadan kalkması,

- Tekrarlı kullanılan iğnelerin sebep olduğu kan yoluyla bulaşan hastalıkların ortadan kalkması gibi önemli avantajlara sahiptirler.

Belirli bölgedeki mukoza ile temas eden bitkilerden elde edilen aşıların avantajlarından biri, lektinler ve saponinler gibi adjuvant özellik gösteren farklı bitki komponentlerini de içermeleridir. Ayrıca bu aşılar gerçekleştirilen insan ve hayvan çalışmalarından oral olarak uygulandıkları yerlerde antijen-spesifik immun yanıtı indüklemişlerdir [36]. Ayrıca gerçekleştirilen farklı çalışmalar, oda sıcaklığında uzun süre stabil olarak kalabildiklerini de göstermiştir [37]. Yine de oral kullanım subunit aşılarda immun cevaplarında var olan çeşitlilikten dolayı ticari olarak başarı elde edilememiştir. Günümüzde bitki aşıları ile yapılan çalışmalar yeterli değildir. Oral kullanımın artırılması için stabilizasyon ve/veya sindirim sistemindeki degradasyondan aşı antijenlerinin korunması ve daha etkili sonuçlar alınması için immun sistemin spesifik bölgelerinin hedeflenmesi ile ilgili çalışmalar yapılmalıdır. Bu anlamda yapılan çalışmalar kapsamında, bitki hücre matriksi içerisinde immunujenin enkapsülasyonunun, gastrik enzimlerden ve asitlerin gerçekleştirdiği degradasyondan korunmayı sağlayabileceği ifade edilmiştir [36]. Covid-19 ile mücadele için aşı geliştirmenin en önemli basamağı, SARS-CoV-2 ile konukçu bağışıklık sistemi arasındaki ilişkinin tam olarak anlaşılmasından geçmektedir. Bu ilişki, hastalığın hafif, şiddetli ya da asemptomatik gelişip gelişmeyeceği üzerinde etkili bir parametredir [1]. Fc füzyon proteinleri, diğer proteinlere bağlanarak ekspresyonlarını kolaylaştırmakta ve proteinin yarı-ömrünün uzamasını sağlamaktadır

Siriwattananon et al. [11], gerçekleştirdikleri bir araştırmada; Nicotiana benthamiana bitkisinde ACE2-Fc terapötik protein üretimine dayalı bir çalışma yapmışlardır. Çalışmada virüsün konak hücre üzerindeki bağlanma bölgelerine tutunmasını önleyen ACE2-Fc füzyon proteininin bitkide üretimi gerçekleştirilmiştir. Gerçekleştirilen in vitro çalışmalarla da enfeksiyonun önlendiği ispatlanmıştır [11]. 
Tablo 1. Bitkilerden elde edilen bazı aşı tipleri, konukçu bitkiler ve antijenlere örnekler

\begin{tabular}{|c|c|c|}
\hline Kategori & Antijen & Konukçu Bitki \\
\hline \multirow{7}{*}{ 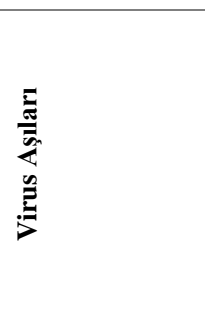 } & \multirow{2}{*}{ HBsAg } & Nicotiana tabacum $\mathrm{L}$. \\
\hline & & Lupinus luteus \\
\hline & HBsAg orta proteini & Solanum tuberosum $\mathrm{L}$. \\
\hline & Şap virüsü yapı proteini & Nicotiana tabacum $\mathrm{L}$. \\
\hline & Şap virüsü yapı poliproteini & Yonca \\
\hline & Norwalk virüsü kapsit proteini & Lycopersicon esculentum \\
\hline & HIV kapsit proteini & Lycium barbarum $\mathrm{L}$. \\
\hline \multirow{6}{*}{ 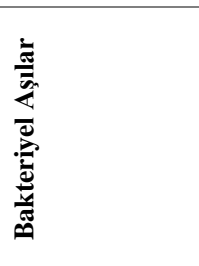 } & \multirow{2}{*}{ Helicobacter pylori üreaz subunit B } & Nicotiana tabacum $\mathrm{L}$. \\
\hline & & Oryza sativa $\mathrm{L}$. \\
\hline & Actinobacillus pleuropneumoniae toksini & Nicotiana tabacum $\mathrm{L}$. \\
\hline & Measles virus hemagglutinin protein cholera toxin B subunit & Lactuca sativa $\mathrm{L}$. \\
\hline & Shiga toksini (tip 2) & Nicotiana tabacum $\mathrm{L}$. \\
\hline & Lyme hastalık ajanı dış yüzeyi A proteini & Nicotiana tabacum $\mathrm{L}$. \\
\hline \multirow{2}{*}{ 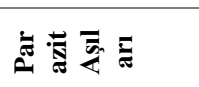 } & Sistiserkozis sentetik peptiti & Carica papaya $\mathrm{L}$. \\
\hline & Entamoeba histolytica'ı Gal/GalNAc lektinleri & Nicotiana tabacum $\mathrm{L}$. \\
\hline
\end{tabular}

Kanada'da bulunan Medicago firmas1, Covid-19'a ait gen sekansı tanımlandıktan 20 gün sonra, Nicotiana benthamiana bitkisini kullanarak VLP'lerin üretimini başarmışlardır. Covid-19'un S proteinini kodlayan gen sekansı Agrobacterium aracılığıyla bitkiye transfer edilmiş ve sonuç olarak bitkide lipit membranını ve $\mathrm{S}$ proteinini içeren bir VLP'nin üretimi gerçekleştirilmiştir. Klasik aşı üretim yöntemlerine göre çok düşük bir miktara mal olan bu ürünün faz 3 denemeleri 2021 Mart ayı içerisinde sürdürülmüştür [10, 38]. Benzer şekilde British American Tobacco şirketinin alt kuruluşu olan Kentucky BioProcessing (KBS) de benzer şekilde virüse ait genetik sekansın bir kısmının Nicaotiana benthamiana bitkisinde üretimini gerçekleştirmiş ve potansiyel bir antijen üretmiştir. Firmaya ait aşı, 2021 Mart ayı içerisinde faz 2 denemelerini yürütmüştür [10, 39]. California Üniversitesi'nde bulunan bir araştırma grubunun Covid-19 ile ilgili gerçekleştirdiği bir çalışmada, SARS-CoV-2 üzerinde bulunan B- ve T- hücre epitopları ile birlikte börülce mozaik virüsü kullanılarak immun cevabı tetikleyen bir tür VLP üretimi sağlanmıştır [10].

McDonald ve Holtz [40], Covid-19 sebebiyle karantinaya giren California bölgesindeki bir çiftlikte toplam maliyeti 1.46 milyon \$ olan ve 350 hektarlık alanda hasat edilmiş marulun üreticinin elinde kaldığını farketmişlerdir. Araştırmacılar, 3 milyon kg yaş marul biyokütlesine tekabül eden bu hasat ürününün Covid-19 tanı kitlerinde kullanılmak üzere rekombinant protein üretiminde kullanılabileceğini ileri sürmüşlerdir. DARPA'nın Blue Angel projesi kapsamında, 2010 yılında bitkilerden terapötik proteinlerin büyük ölçek üretimine 100 milyon \$'lık yatırımı da araştırmacıları bu konuda desteklemektedir [40]. Araştırmacılar, daha önceki yıllarda serada yetiştirilen Nicatiana benthamiana bitkisinde monoklonal antikor üretiminin gerçekleştirilmesi üzerine bir teknoekonomik model geliştirmişlerdir [41]. Bu çalışmadan elde edilen veriler kullanılarak maruldan elde edilmesi düşünülen antijene ait bazı sayısal veriler hesaplanmıştır. Veriler değerlendirildiğinde ise 1 milyar ELISA antijeninin üretimi için 36 hektarlık marul yeterli olurken, aynı miktarda antijen için 60.000 L memeli hücre kültürünün kullanılması gerektiği ileri sürülmüştür. Ayrıca memeli hücre kültürlerinin pahalı besin ortamı bileşenleri ve yüksek laboratuvar özellikleri, bitkileri daha da dikkat çeker hale getirmektedir [40].

İlaç geliştirilmesine ait araştırmalarda moleküler doking/yerleştirme çalışmalarına da önem verilmiştir. Bu biyoinformatik tekniğinde, bir molekülün protein yapısında bulunan başka bir molekül ile etkileşimi modellenmekte ve makromoleküller için ligandların görünür bağlanma modları ve afiniteleri tahmin edilmekte ve belirlenmektedir [42, 43] (Tablo 2). Bu teknikte, moleküllerin farklı durumları göz önünde bulundurularak üç boyutlu uzaydaki moleküllerin etkileşimleri incelenebilmekte, daha ilgili ve önemli farmakolojik etkileşimde yer alan faktörler belirlenebilmektedir [43]. Böylece, moleküler doking yöntemi yüksek maliyetli ve zaman kaybettiren klinik ve laboratuvar çalışmalarından önce tercih edilen bir yöntem haline gelmiştir. Ayrıca, son yıllarda moleküler doking/yerleştirme yöntemlerinin hızı, güvenilirliği ve doğruluğundaki gelişmeler, yapı bazlı ilaçların tasarlanmasında bu yöntemleri uygun bir seçenek haline getirmiştir [3]. Mohammadi and Shaghagi, [43] tarafindan gerçekleştirilen bir çalışmada, sarımsaktan elde edilen dialil disülfit, zerdeçaldan elde edilen kurkumin, biberden elde edilen kapsaisin, kakuleden elde edilen limonen, meyan kökünden elde edilen kumarin, yarbuz bitkisinden elde edilen timol, Stachys schtschegleevi bitkisinden elde edilen verbakosit ve geven bitkisinden elde edilen glukuronik asit metabolitlerinin moleküler doking yöntemi ile Covid-19'a karşı ilaç etkisi incelenmiştir. Tüm metabolitler farklı oranlarda etkili bulunsalar da, Covid-19'a karşı en etkili olan metabolitin kurkumin olduğu belirlenmiştir. 
Tablo 2. Bazı bileşikler ve seçilen antiviral ajanlar arasındaki etkileşim tablosu [44]

\begin{tabular}{clcc}
\hline Bileşik & Ligand & Reseptör & kcal/mol \\
\hline Umifenovir & 6-Ring & CE LYS 118 (A) & -0.6 \\
& N 18 & O ALA 356 (A) & -1.7 \\
Remdevisir & 6-Ring & CB GLU 403 (A) & -0.6 \\
& 5-Ring & CG PRO 407 (A) & -0.5 \\
Ribavirin & 5-Ring & NE1 TRP 220 (A) & -0.5 \\
\hline
\end{tabular}

Psidium guajava L. ve Piper nigrum L.'nin sekonder metabolitlerinin (izokuersetin, terpenil asetat, morin-3-Oliksozit, ginensin ve braçiamit A), koronavirüs hastalığ (Covid-19) ile ilişkili 3 anahtar proteine (viral S proteini, viral $S$ proteininin hedefi olan ACE2 ve viral $S$ proteininin öncül enzimi TMPRSS2) bağlanma açısından tarandığ moleküler doking çalışmasında, incelenen tüm bileşiklerin bu üç reseptöre önemli ölçüde bağlandığı tespit edilmiștir. İncelenen sekonder metabolitler arasından karyofilen, terpenil asetat, morin and morin glikozitlerinin klinik araştırmalar için düşünülebileceği belirtilmiştir [20].

Jena et al. [3] kateşin ve kurkuminin, SARS-CoV-2 virüsünün $\mathrm{S}$ proteini ve konak hücrelerin aynı kökenli reseptörü ACE2 ile etkileşimini moleküler doking/yerleştirme yöntemi kullanılarak belirlemeyi amaçladıkları çalıșmalarında; kateşin ve kurkuminin sadece viral S Proteini ve konakçı reseptör ACE2'ye değil, aynı zamanda onların komplekslerine de (SARS-CoV-2'nin S proteininin reseptör bağlayıcı domaini (RBD) ve ACE2; RBD/ACE2-kompleks) güçlü bağlanma afinitesi sergilediklerini belirlemişlerdir. Kurkumin, viral $\mathrm{S}$ proteininin RBD'ne doğrudan bağlanırken, bunun aksine kateşin S proteininin RBD bölgesi yakınında bulunan amino asit kalıntılarına bağlanmış ve RBD'nin amino asit kalıntılarında ve yakın çevresinde dalgalanmaya neden olmuştur. Elde edilen bulgulara göre, kateşin ve kurkuminin SARS-CoV-2'ye karşı ileriye dönük antiviral ilaçlar için düşünülebileceği rapor edilmiştir. Bundan sonraki çalışmalarda bu bulguları doğrulamak için deneysel çalışmaların yapılması gerektiği vurgulanmıştır [3].

Biyoflavonoitler, çeşitli biyolojik potansiyele sahip bitki kaynaklı polifenolik bileşiklerin en büyük grubunu oluştururlar ve ayrıca SARS ve MERS (Orta Doğu Solunum Sendromu) tedavisinde etkili oldukları da kanıtlanmıştır. Üç SARS-CoV-2 proteini (yapisal olmayan protein-15 Endoribonükleaz-NSP15, SARS-CoV-2'nin S proteininin reseptör bağlayıcı domaini-RBD ve ana proteaz-Mpro / $3 \mathrm{CL}^{\mathrm{pro}}$ ) üzerine bazı flavonoitlerin etkisi, moleküler doking/yerleştirme ile belirlenmeye çalışılmış ve incelenen flavonoidlerden glisirizik asit, amentoflavon ve mulberosit'in SARS-CoV-2 anahtar viral proteinlerini inhibe etmede umut verici potansiyellerinin olduğu belirlenmiştir [45].

Yapılan başka bir moleküler doking çalışmasında; krisin, emetin, tuteolin, kuersetin, amentoflavon, apigenin, hesperetin, neobavaizoflavon, izobavaçalkon, psoralidin, epikateşin gallat, emodin, beta-sitosterol, juglanin, kazinolA, ferruginol, theaflavin-3,3'-digallat fenolik bileşiği, tomentin-D, papiriflavonol metabolitleri SARS-CoV-2'ye karşı kullanılabilecek kapasiteye sahip metabolitler olarak belirlenmiștir. Kristin ve emodinin SARS-CoV-2'in S proteini ve ACE2 arasındaki etkileşimi; Emetin'nin RNA, DNA ve protein sentezini; kuarsetin, amentoflavon, hesperetin, beta-sitosterol, theaflavin-3,3'-digallat ve apigeninnin $3 \mathrm{CL}$ proteazı; neobavaizoflavon, 1sobavaçalkon, psoralidin, tomentin-D ve epikateşin gallatın papain benzeri proteazı $\left(\mathrm{PL}^{\mathrm{pro}}\right)$ ve ferruginolün replikasyonu inhibe ettiği; luteolinin viral girişi engellediği ve papiriflavonol A ve Kazinol A'nın proteaz inhibisyonuna neden olduğu rapor edilmiştir [46]. SARS-CoV-2 spike proteinlerine karş1 stilbenoitlerle yapılan moleküler doking/yerleştirme çalışmasında, stilben bazlı bileşiklerin (özellikle resveratrol) spike proteinini bozmak şeklinde etki eden anti-SARS-CoV2 ilaç adayları olarak düşünülebileceği bildirilmiştir [47].

Pandey et al. [48], moleküler doking/yerleştirme yöntemiyle yaptıkları çalışmada, SARS-CoV-2 spike proteinlerinin inhibisyonunu hedeflemişler ve bu amaçla daha önce antiviral etkinlikleri rapor edilmiş olan 9 flavonoidi (baicalin, kurkumin, galangin, morin, kuersetin, skutellarein, silibinin, mirisetin, epigallokateşin) incelemişlerdir. Taradıkları bu bileşikler arasında SARSCoV-2 spike glikoproteinine karşı en yüksek bağlanma afinitesini baicalinin gösterdiğini tespit etmişledir. Ayrıca çalışmanın devamında yine moleküler doking yöntemi ile baicalinin spike proteinini inhibe edici potansiyeli COVID19 tedavisi için kullanılan iki ilaç (Abacavir ve Hidroksiklorokin) ile karşılaştırıldığında, baicalinin daha iyi inhibe edici potansiyele sahip olduğu ortaya konmuştur. Kumar et al. [49] SARS-CoV-2 virüs inhibisyonunda hedef olarak daha önceki salgına neden olan diğer SARS-CoV'ye \%89 benzerlik gösterdiği için Nsp15 proteinini seçmişler ve moleküler doking yöntemi ile farklı fitokimyasal maddelerin Nsp15 proteini ile bağlanma potansiyellerini incelemişlerdir. Çalışmada yaklaşık 50 fitokimyasalın Nsp15 ile bağlanma potansiyeli gösterdiği tespit edilmiş ve bu fitokimyasalların viral replikasyonu inhibe edebilme potansiyellerinin olabileceği rapor edilmiştir. İncelenen fitokimyasallardan bazıları; sarsasapogenin, kurkumin, ajmalisin, novobiosin, silmarin ve aranotin, piperin, gingerol, rosmarinik asit ve alfa terpinil asetattır.

\section{Bitkisel sekonder metabolitlerin kullanımı ve covid- 19 ile mücadele}

Bitkisel sekonder metabolitler, bitkinin doğal yaşam döngüsünün devamı için gerekli olmamakla birlikte, bitkilerin çevre ile olan adaptasyonlarında büyük önem taşıyan metabolitlerdir [50]. Bitkilerde bulunan sekonder metabolitlerin çeşitli biyolojik ve ekolojik özellikleri mevcuttur. Özellikle kimyasal savunmadaki antioksidatif ve antimikrobiyal etkileri çok önemlidir. Moleküler çiftçilikte, bitkilerin bu özellikleri değerli sekonder metabolitlerin büyük ölçek üretimleri amacıyla kullanılmaktadır. Ayrıca metabolizma mühendisliği devreye sokularak biyoaktif bileşiklerin üretimindeki kısıtlar ortadan kaldırılabilmekte ve biyoprosesler devreye sokularak verimlilik artırılabilmektedir [10]. Bitkilerde moleküler çiftçilik kullanılarak farklı biyolojik ve farmasötik ürünlerin üretiminin en önemli avantajı, düşük maliyetli ve 
ölçeklenebilir olmasının yanı sıra, varolan Covid-19 pandemisi gibi acil durumlarda endüstriyel ölçekte hızlı üretime imkan vermeleridir [1].

Covid-19 pandemisi hızlı şekilde bulaşması ve yüksek ölüm oranları ile acil önlemler ve tedavi yöntemlerinin geliştirilmesine ihtiyaç duyulan bir süreçtir. Salgının 180 ülkede görülmüş olması ve ölüm oranlarının yüksek olması nedenleriyle hızla yeni ilaç keşiflerine ihtiyaç vardır. Halk tıbbında geniş yer bulan tıbbi bitkiler, biyoaktif ve fitokimyasal madde içeriklerinin zengin olması nedeniyle yeni ilaçların geliştirilmesinde ciddi potansiyele sahiptirler [15]. Gerçekleştirilen çalışmalarda, virüs kaynaklı enfeksiyonların önlenmesinde çoğunluğu bitkilerden elde edilen proteaz inhibitörlerinin son derece etkili olduğu belirlenmiştir [44].

Tarih öncesi dönemden beri insanlar, bitkilere ait farklı kısımları, enfeksiyöz hastalıklar da dahil olmak üzere çok çeşitli hastalıkların tedavisinde kullanmışlardır [9]. 18. yy'ın başlarına kadar yaklaşık olarak 13 bin bitki türü tıbbi amaçlarla değerlendirilmiştir. Günümüzde ise bu sayı yaklaşık 20 bine yaklaşmışıtır. Tıbbi-aromatik bitkiler; fitokimyasal maddeleri içeren ve bu maddeler sayesinde bazı ilaç bileşimlerine girebilen, hastalıkların tedavisinde doğrudan ya da işlenerek kullanılan bazı bitki türleri olarak tanımlanmaktadır [51]. Bazı tıbbi bitkilerin antiviral özelliklere sahip olduğu bildirilmiştir. Polifenoller, flavonoitler, alkaloitler, kinonlar, kumarinler, terpenler, proantosiyanidinler, ligninler, tanenler, polisakkaritler, steroitler, tiyosülfonatlar ve saponinler, viral enfeksiyonlarla savaştığ 1 gözlenen başlıca fito-bileşenlerdir [4]. Koruyucu ve tamamlayıcı tıp olarak adlandırılan ve tıbbi özellikleri bulunan bitkilerin veya bu bitkilerden elde edilen çeşitli formulasyonların kullanımı ile çeşitli hastalıkların semptomlarının iyileştirilmesinin yanı sıra, viral enfeksiyonların tedavisi de başarılı şekilde gerçekleştirilmiştir. Nim bitkisi (ya da yalancı tespih ağacı) olarak da adlandırılan Azadirachta indica'ya ait tohumlar kullanılarak elde edilen Praneem adlı formulasyon HIV tedavisinde başarılı şekilde uygulanmıştır [15]. Çin'de bulunan 31 bölgenin 23'ünün sağlık otoriteleri, Covid-19 salgınının yayılmasının önlenmesinde bitkisel tedavilerin işe yaradığını belirtmişlerdir. Bu bölgelerde en sık kullanılan bitkisel formüller Radix astragali (Huangqi) ve Glycyrrhizae radix Et Rhizoma (Gancao)'dır [10].

Son zamanlarda yapılan birkaç çalışmada kateşinler (yeşil çay kateşinleri) ve kurkumin (diferuloilmetan; zerdeçaldan) gibi doğal polifenolik bileşiklerin İnsan İmmün Yetmezlik Virüsü (HIV), Herpes Simplex Virüsü, İnfluenza virüsü, Hepatit $B$ ve $C$ virüsleri (sirasıyla $H B V$ ve $H C V$ ), Adenovirüs, Zika virüs, Chikungunya virüsü (CHIKV) gibi geniş bir virüs yelpazesine karşı antiviral aktivitelere sahip olduğu rapor edilmiştir [3, 4]. Her iki polifenolik bileşiğin antiviral aktivitelerini açıklamak için çeşitli mekanizmalar öne sürülmüştür. Örneğin, yeşil çay kateşinlerinin viral giriş ve replikasyonunun potansiyel bir baskılayıcısı olduğu, kurkuminin ise guanin nükleotidinin de novo sentezinde hız sınırlayıcı bir enzim olan monofosfat dehidrojenazın güçlü bir inhibitörü olduğu gösterilmiştir. Ayrıca, yapılan bazı hayvan deneylerinde, yeşilçay kateşinleri ve kurkuminin
ACE2'nin ekspresyonunu inhibe ettiği de gözlemlenmiştir [3].

Bitkisel terapi ve tıbbi bitkilerin kullanımının son derece etkili bir teknik olduğu 2003 yılında yaşanan SARS epidemisinde ispatlanmıştır. Birçok ülke SARS ile mücadelelerinde bitkilerden yararlanmıştır. Çok sayıda araştırmacı, 2003 yılında başlamak üzere çok sayıda sekonder metabolitin ve antiviral ekstraktın SARS-CoV üzerindeki etkilerini incelemeye başlamıştır. $\mathrm{Bu}$ amaçla 200'den fazla bitki taranmıştır [52].

Glisirhizinin HIV ve Ağır Akut Solunum Yolu Yetersizliği Sendromu (Severe Acute Respiratory Syndrome, SARS) benzeri virüslere karşı etkili olduğu rapor edilmiştir [53]. Cinatl et al. [54]; SARS hastalarından alınan iki klinik koronavirüs izolatına (FFM-1 ve FFM-2) karşı ribavirin, 6-azauridin, pirazofurin, mikofenolik asit ve glisirizinin antiviral potansiyelini araştırmışlar ve ticari olarak mevcut olan bu bileşikler hastalarda antiviral, antitümör ve immünosupresif aktiviteleri için kullanılmışlardır. Çalışma sonunda, inceledikleri tüm bileşikler arasında SARS ile ilişkili virüsün replikasyonunu önlemede en aktif bileşiğin glisirizin olduğu bulunmuştur. Virüs replikasyonunun inhibisyonuna ek olarak, glisirizinin, replikatif döngünün erken aşamalarında virüsün adsorpsiyonunu ve penetrasyonunu da inhibe ettiği rapor edilmiştir. Glisirizin, hem adsorpsiyon periyodu sırasında hem de sonrasında verildiğinde en etkili bulunmuştur (EC50 $300 \mathrm{mg} / \mathrm{L}$ ).

Covid-19 ile mücadele kapsamında gerçekleştirilen çalışmalarda, insanların bağış̧ılık sistemlerini desteklemek üzere bitkileri kullanmaları konusunda teşvik edilmeleri ve viral enfeksiyonların baskılanması amaciyla probiyotikler gibi fonksiyonel gıdalarla ilgili araştırmaların arttırılmasına ihtiyaç duyulmaktadır. Naja ve Hamdeh (2020), pandemi sürecinde bireysel, sosyal ve milli seviyelerde optimal beslenmeyi destekleyen çok seviyeli aksiyon planı belirlemişlerdir. $\mathrm{Bu}$ çalışmada asıl amaçlar, sağlıklı beslenmenin sürdürülmesi ve aynı zamanda kullanılabilen tüm bitkisel ürünler ile bitki türevleri hakkında kapsamlı bir bilimsel veri tabanının oluşturulmasına yöneliktir [6].

Doğal bir eczane olarak görev yapan ülkemizin sahip olduğu derin etnobotanik bilgi birikimi dikkate alındığında, topraklarımızın Covid-19 tedavisinde kullanım potansiyeli bulunan pek çok bitkiye ev sahibi olduğu görülmektedir. Sahip oldukları güçlü antioksidan ve antimikrobiyal aktivitenin yanı sıra, antiviral aktivitesi de yüksek olan ve bağışıklı sistemini güçlendirme özelliği ile farklı ülkelerde de dikkatleri üzerine çeken laden (Citus spp.), zeytin yaprağ 1 (Olea europea L.), meyan kökü (Glyrrhiza glabra L.) ve farklı kekik cinslerinin (Origanum, Thymus ve Thymbra) Covid-19 tedavisi için potansiyele sahip olarak görülmektedir [15]. Özellikle terpenoitler, alkaloitler, stilbenler ve flavonoitlerin bitkisel bazlı anti-viral ilaçların üretilmesi için temel biyolojik aktiviteye sahip metabolitler oldukları düşünülmektedir [6]. Şimdiye kadar; arktin, skutelarin, forsitozit, kaempferol, sekoksiloganin, nikotianamin, saikosaponin gibi çeşitli fitokimyasal bileşiklerin anti-SARS-CoV-2 aktivitesine sahip oldukları bildirilmiştir [8] (Tablo 3). 
Tablo 3. Koronavirüslerle mücadelede kullanılan çeşitli bitki sekonder metabolitleri*

\begin{tabular}{|c|c|c|c|c|c|}
\hline Sekonder Metabolit & Bitki & Etkili Olduğu Virüs & Etkili Olduğu Hedef & IC $_{50}$ Değeri** & Kaynak \\
\hline 3'-O-metildiplakol & Paulownia tomentosa & SARS-CoV & PL pro inhibisyonu & $9.5 \mu \mathrm{M}$ & {$[55]$} \\
\hline 3'-O-metildiplakon & Paulownia tomentosa & SARS-CoV & $\mathrm{PL}^{\text {pro }}$ inhibisyonu & $13.2 \mu \mathrm{M}$ & {$[55]$} \\
\hline 4'-O-metildiplakol & Paulownia tomentosa & SARS-CoV & $\mathrm{PL}^{\text {pro }}$ inhibisyonu & $9.2 \mu \mathrm{M}$ & {$[55]$} \\
\hline 4'-O-metildiplakon & Paulownia tomentosa & SARS-CoV & $\mathrm{PL}^{\mathrm{pro}}$ inhibisyonu & $12.7 \mu \mathrm{M}$ & {$[55]$} \\
\hline 4'-O-metilbavaçalkon & Psoralea corylifolia & SARS-CoV & $\mathrm{PL}^{\mathrm{pro}}$ inhibisyonu & $10.1 \mu \mathrm{M}$ & {$[56]$} \\
\hline $\begin{array}{l}\text { 6-geranil-4',5,7- } \\
\text { trihidroksil-3',5'- } \\
\text { dimetoksiflavanon }\end{array}$ & Paulownia tomentosa & SARS-CoV & $\mathrm{PL}^{\mathrm{pro}}$ inhibisyonu & $13.9 \mu \mathrm{M}$ & {$[55]$} \\
\hline Amentoflavon & Torreya nucifera & SARS-CoV & $3 \mathrm{CL}^{\mathrm{pro}}$ inhibisyonu & $8.3 \mu \mathrm{M}$ & {$[57]$} \\
\hline Apigenin & Torreya nucifera & SARS-CoV & $3 \mathrm{CL}^{\mathrm{pro}}$ inhibisyonu & $280.8 \mu \mathrm{M}$ & {$[57]$} \\
\hline Baikalein & Scutellaria baicalensis & SARS-CoV-2 & $3 \mathrm{CL}^{\text {pro }}$ inhibisyonu & $0.39 \mu \mathrm{M}$ & {$[58]$} \\
\hline Baikalin & Scutellaria baicalensis & SARS-CoV & & $11 \mu \mathrm{g} / \mathrm{ml}$ & {$[59]$} \\
\hline Bavaçinin & Psoralea corylifolia & SARS-CoV & $\mathrm{PL}^{\text {pro }}$ inhibisyonu & $38.4 \mu \mathrm{M}$ & {$[55]$} \\
\hline \multirow{4}{*}{ Broussoçalkon-B } & \multirow{4}{*}{ Broussonetia papyrifera } & SARS-CoV & $3 \mathrm{CL}^{\mathrm{pro}}$ inhibisyonu & $57.8 \mu \mathrm{M}$ & {$[59]$} \\
\hline & & SARS-CoV & $\mathrm{PL}^{\mathrm{pro}}$ inhibisyonu & $11.6 \mu \mathrm{M}$ & \\
\hline & & MERS-CoV & $3 \mathrm{CL}^{\mathrm{pro}}$ inhibisyonu & $27.9 \mu \mathrm{M}$ & \\
\hline & & MERS-CoV & PL $^{\text {pro inhibisyonu }}$ & $112.9 \mu \mathrm{M}$ & \\
\hline Dihidrotanşinon & Salvia miltiorrhiza & MERS-CoV & Viral girişin inhibisyonu & $1 \mu \mathrm{g} / \mathrm{mL}$ & {$[61]$} \\
\hline Diplakon & Paulownia tomentosa & SARS-CoV & $\mathrm{PL}^{\mathrm{pro}}$ inhibisyonu & $10.4 \mu \mathrm{M}$ & {$[55]$} \\
\hline Emodin & $\begin{array}{l}\text { Rheum ve Polygonum } \\
\text { cinslerinin ana bileşenleri }\end{array}$ & SARS-CoV & $\begin{array}{l}\text { S proteininin ACE2'ye } \\
\text { bağlanmasını engeller }\end{array}$ & $200 \mu \mathrm{mol} / \mathrm{L}$ & {$[62]$} \\
\hline Essin & Aesculus hippocastanum & SARS-CoV & & $6.0 \mu \mathrm{M}$ & {$[63]$} \\
\hline Gallokateşin gallat & Pichia pastoris & SARS-CoV & $3 \mathrm{CL}^{\mathrm{pro}}$ inhibisyonu & $47 \mu \mathrm{M}$ & {$[64]$} \\
\hline Glisirizin & Glycyrrhiza glabra & SARS-CoV & Virüsreplikayonunun inhibisyonu & $300 \mathrm{mg} / \mathrm{L}$ & {$[54]$} \\
\hline Hesperetin & Isatis indigotica & SARS-CoV & $3 \mathrm{CL}^{\text {pro }}$ inhibisyonu & $8.3 \mu \mathrm{M}$ & {$[65]$} \\
\hline Hirsutenon & Alnus japonica & SARS-CoV & $\mathrm{PL}^{\mathrm{pro}}$ inhibisyonu & $4.1 \mu \mathrm{M}$ & {$[66]$} \\
\hline İguesterin & Triterygium regelii & SARS-CoV & $3 \mathrm{CL}^{\mathrm{pro}}$ inhibisyonu & $2.6 \mu \mathrm{M}$ & {$[67]$} \\
\hline İzobavaçalkon & Psoralea corylifolia & SARS-CoV & $\mathrm{PL}^{\text {pro }}$ inhibisyonu & $7.3 \mu \mathrm{M}$ & {$[56]$} \\
\hline \multirow{4}{*}{ İzolikuiritigenin } & \multirow{4}{*}{ Broussonetia papyrifera } & SARS-CoV & $3 \mathrm{CL}^{\text {pro }}$ inhibisyonu & $61.9 \mu \mathrm{M}$ & {$[59]$} \\
\hline & & SARS-CoV & $\mathrm{PL}^{\mathrm{pro}}$ inhibisyonu & $24.6 \mu \mathrm{M}$ & \\
\hline & & MERS-CoV & $3 \mathrm{CL}^{\text {pro }}$ inhibisyonu & $33.9 \mu \mathrm{M}$ & \\
\hline & & MERS-CoV & $\mathrm{PL}^{\mathrm{pro}}$ inhibisyonu & $82.2 \mu \mathrm{M}$ & \\
\hline
\end{tabular}


Tablo 3 (Devamı). Koronavirüslerle mücadelede kullanılan çeşitli bitki sekonder metabolitleri*

\begin{tabular}{|c|c|c|c|c|c|}
\hline Sekonder Metabolit & Bitki & Etkili Olduğu Virüs & Etkili Olduğu Hedef & IC $_{50}$ Değeri** & Kaynak \\
\hline \multirow{4}{*}{ Kaempferol } & \multirow{4}{*}{ Broussonetia papyrifera } & SARS-CoV & $3 \mathrm{CL}^{\text {pro }}$ inhibisyonu & $116.3 \mu \mathrm{M}$ & \multirow{4}{*}[59]{} \\
\hline & & SARS-CoV & PL ${ }^{\text {pro }}$ inhibisyonu & $16.3 \mu \mathrm{M}$ & \\
\hline & & MERS-CoV & $3 \mathrm{CL}^{\text {pro }}$ inhibisyonu & $35.3 \mu \mathrm{M}$ & \\
\hline & & MERS-CoV & $\mathrm{PL}^{\mathrm{pro}}$ inhibisyonu & $206.6 \mu \mathrm{M}$ & \\
\hline Korilifol-A & Psoralea corylifolia & SARS-CoV & $\mathrm{PL}^{\mathrm{pro}}$ inhibisyonu & $32.3 \mu \mathrm{M}$ & {$[56]$} \\
\hline \multirow{5}{*}{ Kuersetin } & Houttuynia cordata Thunb. & $\begin{array}{l}\text { Murin koronavirüs } \\
(\mathrm{M}-\mathrm{CoV})\end{array}$ & $3 \mathrm{CL}^{\text {pro }}$ inhibisyonu & $125 \mu \mathrm{g} / \mathrm{mL}$ & {$[68]$} \\
\hline & Torreya nucifera & SARS-CoV & $3 \mathrm{CL}^{\text {pro }}$ inhibisyonu & $23.8 \mu \mathrm{M}$ & {$[58]$} \\
\hline & \multirow{3}{*}{ Broussonetia papyrifera } & SARS-CoV & $3 \mathrm{CL}^{\text {pro }}$ inhibisyonu & $52.7 \mu \mathrm{M}$ & \multirow{3}{*}[60]{} \\
\hline & & SARS-CoV & $\mathrm{PL}^{\mathrm{pro}}$ inhibisyonu & $8.6 \mu \mathrm{M}$ & \\
\hline & & MERS-CoV & $3 \mathrm{CL}^{\mathrm{pro}}$ inhibisyonu & $34.8 \mu \mathrm{M}$ & \\
\hline \multirow{4}{*}{ Kuersetin- $\beta$-galaktozit } & \multirow{4}{*}{ Broussonetia papyrifera } & SARS-CoV & $3 \mathrm{CL}^{\mathrm{pro}}$ inhibisyonu & $128.8 \mu \mathrm{M}$ & \multirow{4}{*}[60]{} \\
\hline & & SARS-CoV & $\mathrm{PL}^{\text {pro }}$ inhibisyonu & $51.9 \mu \mathrm{M}$ & \\
\hline & & MERS-CoV & $3 \mathrm{CL}^{\mathrm{pro}}$ inhibisyonu & $68.0 \mu \mathrm{M}$ & \\
\hline & & MERS-CoV & $\mathrm{PL}^{\text {pro }}$ inhibisyonu & $129.4 \mu \mathrm{M}$ & \\
\hline Ksantoangenol-E & Angelica keiskei & SARS-CoV & $3 \mathrm{CL}^{\mathrm{pro}}$ ve $\mathrm{PL}^{\text {pro }}$ inhibisyonu & & [69] \\
\hline Luteolin & Torreya nucifera & SARS-CoV & $3 \mathrm{CL}^{\mathrm{pro}}$ inhibisyonu & $20.2 \mu \mathrm{M}$ & {$[58]$} \\
\hline Mimulon & Paulownia tomentosa & SARS-CoV & $\mathrm{PL}^{\mathrm{pro}}$ inhibisyonu & $14.4 \mu \mathrm{M}$ & {$[55]$} \\
\hline Neobavaizoflavon & Psoralea corylifolia & SARS-CoV & $\mathrm{PL}^{\mathrm{pro}}$ inhibisyonu & $18.3 \mu \mathrm{M}$ & {$[56]$} \\
\hline Psoralidin & Psoralea corylifolia & SARS-CoV & $\mathrm{PL}^{\mathrm{pro}}$ inhibisyonu & $4.2 \mu \mathrm{M}$ & {$[56]$} \\
\hline Pristimerin & Triterygium regelii & SARS-CoV & $3 \mathrm{CL}^{\mathrm{pro}}$ inhibisyonu & $5.5 \mu \mathrm{M}$ & [67] \\
\hline Selastrol & Triterygium regelii & SARS-CoV & $3 \mathrm{CL}^{\text {pro }}$ inhibisyonu & $10.3 \mu \mathrm{M}$ & {$[67]$} \\
\hline Sefarantin & Stephania japonica & SARS-CoV-2 & $\begin{array}{l}\text { Viral giriş ve replikasyonun } \\
\text { inhibisyonu }\end{array}$ & $0.98 \mu \mathrm{mol} / \mathrm{L}$ & {$[70]$} \\
\hline Sinigrin & Isatis indigotica & SARS-CoV & $3 \mathrm{CL}^{\mathrm{pro}}$ inhibisyonu & $217 \mu \mathrm{M}$ & {$[65]$} \\
\hline Tingenon & Triterygium regelii & SARS-CoV & $3 \mathrm{CL}^{\text {pro }}$ inhibisyonu & $9.9 \mu \mathrm{M}$ & {$[67]$} \\
\hline Tomentin-A & Paulownia tomentosa & SARS-CoV & $\mathrm{PL}^{\mathrm{pro}}$ inhibisyonu & $6.2 \mu \mathrm{M}$ & {$[55]$} \\
\hline Tomentin-B & Paulownia tomentosa & SARS-CoV & $\mathrm{PL}^{\mathrm{pro}}$ inhibisyonu & $6.1 \mu \mathrm{M}$ & {$[55]$} \\
\hline Tomentin-C & Paulownia tomentosa & SARS-CoV & $\mathrm{PL}^{\mathrm{pro}}$ inhibisyonu & $11.6 \mu \mathrm{M}$ & {$[55]$} \\
\hline Tomentin-D & Paulownia tomentosa & SARS-CoV & $\mathrm{PL}^{\mathrm{pro}}$ inhibisyonu & $12.5 \mu \mathrm{M}$ & {$[55]$} \\
\hline Tomentin-E & Paulownia tomentosa & SARS-CoV & $\mathrm{PL}^{\mathrm{pro}}$ inhibisyonu & $5.0 \mu \mathrm{M}$ & {$[55]$} \\
\hline Triptantrin & Strobilanthes cusia & HCoV-NL63 & 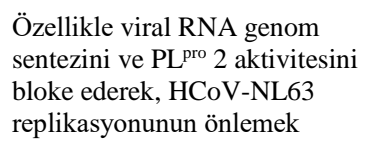 & $1.52 \mu \mathrm{M}$ & {$[71]$} \\
\hline
\end{tabular}

* SARS-CoV-Severe Acute Respiratory Syndrome=Ağır Akut Solunum Yolu Yetmezliği Sendromu; 3CL ${ }^{\text {pro }-3-C h y m o t r y p s i n-L i k e ~ P r o t e a s e=3-K i m o t r i p s i n ~}$ Benzeri Proteaz; PL ${ }^{\text {pro }}$-Papain Like Protease=Papain Benzeri proteaz; MERS-Middle East Respiratory Syndrome=Orta Doğu Solunum Sendromu; ACE2Angiotensin-Converting Enzyme 2=Anjiyotensin Dönüştürücü Enzim 2; M-CoV-Murin Koronavirüs; HCoV-NL63-HCoV-NL63 Korona Virüsü $* * \mathrm{IC}_{50}=$ yar1-maksimum inhibisyon konsantrasyonu

Sahip oldukları terapötik özelliklerinden dolayı, allopatik ilaçlara göre daha az yan etki göstermeleri nedeniyle, bitkilerin Covid-19 tedavisinde kullanımı farklı araştırmacılar tarafindan önerilmiştir. Polifenoller başta olmak üzere bitkilerden elde edilen çeşitli fitokimyasalların (flavonoitler, gallateler ve kuersetinler vb.), Covid-19 dahil olmak üzere koronavirüslerin proliferasyonunu önlediği belirlenmiştir. $\mathrm{Bu}$ ürünlerin farmasötik formulasyon ya da fonksiyonel gıda olarak kullanımı mümkün olabilmektedir. Artemisia kermanensi, Eucalyptus caesia, Mentha spp. Rosmarinus officinalis, Satureja hortensis ve Zataria multiflora yüksek fenolik içerikleri ile bu amaçla kullanılabilecek bitkilerdir. Ayrıca yapılan araştırmalar sonucunda, Torreya nucifera'da bulunan biflavonoitlerin SARS-CoV 3CL pro replikasyonunu inhibe ettiği de gösterilmiştir [10]. SARS-CoV 3CL pro, viral replikasyon sırasında koronavirüsün davranışlarını düzenleyen önemli bir viral enzimdir. Bu enzimin varlığı, enfekte olmuş konak hücrede SARS koronavirüslerinin replikasyonunun sağlanmasında kritik önem taşımaktadır. Gerçekleştirilen başka bir çalışmada, Isatis indigotica bitkisinden elde edilen ve anti-viral özellikleri olduğu bilinen betasitosterol, hesperetin, aloe emodin, indigo ve sinigrin fenolik bileşiklerinin, enzimin etkisini sınırlandırdıkları tespit edilmiştir. Çalışmada elde edilen IC50 değerleri sırasıyla $1210,365,8.3,752$ ve $217 \mu$ molar olarak belirlenmiştir. 
Ayrıca doğal yollarla elde edilmiş 720 metabolitin bu enzim üzerindeki etkileri incelenmiş ve Pu'er (geleneksel Çin fermente çayı) ve siyah çaydan elde edilen theaflavin-3, 30digallat, 3-isotheaflavin-3-gallat ve tannik asit metabolitlerinin etkin şekilde enzimi inhibe ettikleri belirlenmiştir [9]. Ayrıca Senna bitkisinin yapraklarından alınan ekstratların Covid-19 hastalarında semptomları iyileştirdiği belirtilmiştir. Geleneksel Çin tıbbı formulasyonlarından olan ve 13 farklı bitkinin karışımını içeren Lianhuanqingwen (LH)'nin ise SARS-CoV-2 replikasyonunu baskıladığ 1 , proinflamatuar sitokin üretimini azalttı̆ğ ve SARS-CoV-2 hücrelerinde yapısal değişikliğe sebep olduğu gösterilmiştir. Ayrıca in vitro denemelerde LH'nin SARS-CoV-2'ye karşı antiviral aktivite gösterdiği de ispatlanmıştır [10].

Kınakına ağacı (chincona) kabuğundan elde edilen kinin, önemli bir alkaloittir. Sentetik bir kinin türevi olan klorokininin, biyouyumluluğu nedeniyle sahip olduğu DNAinterkalasyon özelliklerini, koronavirüslerin semptomlarının azaltılmasında etkili olduğu, bu şekilde SARS-CoV-2 için iyi bir ilaç adayı olduğu düşünülmüştür [9]. Ancak çalışmalar sırasında vertiküler aritmi, kutanöz ters reaksiyonlar ve ateşli karaciğer yetmezliği gibi ciddi yan etkiler ile karşılaşılmıştır. Yan etkilerine rağmen yine de doğal kinin türevleri ve analoglarının semptomların azaltılmasında etkili olduğu görülmüştür. Benzer şekilde Rauwolfia serpentina bitkisine ait kuru köklerden elde edilen reserpin alkaloitinin de SARS-CoV'un replikasyonunu inhibe ettiği belirlenmiştir. Ayrıca palmatin ve çelidoin de Covid-19 ile mücadelede etkili olabileceği düşünülen diğer alkaloitlerdir [7].

Kompleks oluşturma kabiliyetine sahip çeşitli heterosiklik moleküller, giriş inhibitörü ilaçların geliştirilmesinde kullanılabilmektedir [12]. Aromatik halkaları ve hidroksil (-OH) grupları ile bilinen flavon glikozitleri, fenolikler ve polifenolik bileşikler de gösterdikleri antiviral etkileri nedeniyle birçok araştırmacı tarafından önerilmişlerdir. Hidroksil gruplarının viral protein aktivitelerini, proteinlerin pozitif yüklü amino grupları ile hidrojen bağları kurarak inhibe ettikleri düşünülmektedir. Polifenoller ise, viral zarfin lipoprotein tabakaları arasına girmekte ve virüsün konak hücreye girişini engellemektedir. Örneğin; Rheum ve Polygonum bitkilerinden elde edilen krisin flavonoidi, S proteini üzerinde etkili olmuş ve ACE2 interaksiyonunu etkilemiştir [7].

Esansiyel yağlar; viral zarfın çift lipit tabakasının arasına yerleşmekte ve membran akışkanlığına etki etmektedir. Yapılan araştırmalar lipofilik yapıları nedeniyle monoterpen, oksijenli seksiterpenler ve fenilpropanoitlerin, koronavirüslerin bilayer fosfolipit tabakasının içine yerleştiğini göstermiştir. Ökaliptüs (Eucaliptus spp.) ağacından elde edilen ökaliptol esansiyel yağının ise, başta SARS-CoV-2 olmak üzere koronavirüsler üzerinde etkili bir antiviral bileşik olduğu belirlenmiştir. Bu antiviral özellik ise metabolitin ether $(-\mathrm{O})$, keton $(=\mathrm{O})$ ve hidroksil $(-\mathrm{OH})$ gruplarına bağlanmıştır [9].

Gerçekleştirilen başka bir çalışmada ise, Stephania tetrandra ve Menispermaceae ailesinin benzer bitkilerinden elde edilen farmasötik olarak önemli 3 bis-benzilizokinolin alkaloitinin (sefarantin-CEP, fangkinolin-FAN ve tetrandrin-TET) $\mathrm{HCoV}-\mathrm{OC} 43$ koronavirüsü ile enfarkte olmuş MRC-5 insan akciğer hücrelerindeki etkileri saptanmıştır. $\mathrm{Bu}$ metabolitler, ayrıca anti-inflamatuar ve anti-kanser aktivite de göstermektedirler. Çalışma sonucunda metabolitlerin $\mathrm{HCoV}-\mathrm{OC} 43$ 'ün konukçu hücre içerisinde replikasyonunun ciddi oranda düştüğü ve IC50 değerlerinin CEP, FAN ve TET için sırası ile $0.83,1.01$ ve 0.33 olduğu belirtilmiştir. Ayrıca $\mathrm{N}$ ve $\mathrm{S}$ proteinlerinin ekspresyonu da bu üç metabolit tarafından sınırlandırılmıştır [9].

Bitkilerden sekonder metabolitlerin üretimi; bitki genetiği, çevresel faktörler, iklim, mevsim, büyüme periyodu, bitki kısmı, hasat öncesi ve sonrasındaki işlemlerin yanı sıra, ekstraksiyon tekniklerine de bağlı olarak değişiklik gösterebilmektedir. Tüm bu faktörler, klasik yöntemlerle sekonder metabolit üretimini kisttlamakta, bu noktada ise bitki doku kültürü uygulamaları devreye girmektedir [50]. Bitki doku kültürü, farklı bitki hücreleri, organları veya dokularının totipotensi özelliğinden faydalanmak adına aksenik koşullarda kültüre alınması işlemidir [72]. Bitki doku kültürlerinin kullanımının en büyük avantajı, sekonder metabolizmanın savunma cevabının tetiklenmesi ile aktive olmasıdır. $\mathrm{Bu}$ tetiklenme, üretilen metabolit miktarının biyotik ya da abiyotik stres sonucu elisitasyon ile artmasını sağlamaktadır [7]. Elisitasyon, in vitro ve ex vivo gelişen bitkilerde biyokütlenin ve sekonder metabolit üretimlerinin artırılması olarak tanımlanmaktadır [73]. Elisitasyonda kullanılan elisitörler, bu işlemi sinyal iletim kaskatlarına müdahale ederek gerçekleştirirler [49].

\section{Sonuçlar}

Koronavirüsler, toplum sağlığını tehdit eden ve ölümcül sonuçlar doğuran virüsler olmalarına rağmen, antiviral ilaç geliştirilmesine yönelik çalışmalar sadece SARS ve MERS üzerinde yoğunlaşmıştır. Çeşitli hayvan modelleri ve hücre kültürü çalışmaları kullanılarak yapılan araştırmalar ile virüslerin konakçı hücreye girişini veya çoğalma hızını azaltıcı pek çok ilaç adayı üretilmiştir. Covid-19 kaynaklı semptomların ve ölüm oranlarının azaltılması amacıyla uygun tedavilerin geliştirilmesi ile ilgili çalışmalar devam etmekle birlikte, günümüzde hala başarı sağlanamamıştır. Özellikle virüsün hızlı mutasyona uğrama özelliği nedeniyle yeni formulasyonların ve alternatif tekniklerin denenmesine ihtiyaç duyulmaktadır. Covid-19 pandemisi çok hızlı değişen ve çok hızlı gelişen bir durumdadır. DSÖ, hastalık ve ölüm oranlarını düzenli olarak takip etmekte ve paylaşmaktadır. Modern batı tıbbı, henüz Covid-19 tedavisi için tamamen etkili bir yöntem önerememiştir.

Khan et al., [7], Covid-19 ile mücadele araştırmaları devam ederken, bitkiler aleminin araştırılması gereken önemli bir alan olduğunu belirtmişlerdir. DSÖ, dünya üzerindeki hastalıkların tedavisinin $\% 80$ 'inin bitkilerle gerçekleştirildiğini bildirmiştir. Ancak aşırı hasat ve bilinçsiz/dikkatsiz bir şekilde gerçekleştirilen toplama işlemleri, bitkisel popülasyonlara zarar vererek çoğunun yok olma tehlikesi ile karşı karşıya kalmasına neden olmaktadır.

Bitkisel ilaçların tamamen güvenli olduğu ve hiçbir yan etkisinin bulunmadığı düşüncesi tamamen yanlış bir bakış 
açısıdır. Farklı bitkilerde birbirlerinden farklı çok sayıda toksik bileşik bulunmaktadır. $\mathrm{Bu}$ sebeple, bitkilerde sekonder metabolizma yolaklarının detaylıca incelenmesi, güvenli kullanım için önemlidir. Benzer şekilde önemli olan diğer faktörler de coğrafya ve iklimsel koşulların sekonder metabolit çeşitliliği üzerindeki etkisidir. Bu noktada tüm bu sorunların çözümünde bitki biyotekolojisi bir araç olmaktadir.

Bitki bazlı biyolojik üretim sistemlerinin, acil üretim çalışmaları için üretim ana hatlarını hızla değiştirme yeteneği, pandemik durumlar için büyük bir avantaj olarak görülmektedir. Mevcut pandemik durum dikkate alındığında özellikle aşının dünya genelindeki tüm ülkelere dağıtımında ciddi sıkıntılar yaşandığı ortaya çıkmıştır. $\mathrm{Bu}$ nedenle fermantasyon tabanlı ürün sistemlerinin maliyetinin yaklaşık \%50'si olarak düşünülen nispeten düşük maliyetli bitki tabanlı biyolojik üretim platformları, halihazırda ilaç endüstrisinden yoksun olan ülkeler için çok önemli bir değer sunmaktadır.

\section{Çıkar çatışması}

Yazarlar çıkar çatışması olmadığını beyan etmektedir.

\section{Benzerlik oranı (iThenticate): $\% 6$}

\section{Kaynaklar}

[1] K. Dhama, N. Senthilkumar, M.I. Yatoo, S.K. Patel, R. Tiwari, S.K. Saxena and H. Harapan, Plant-based vaccines and antibodies to combat COVID-19: current status and prospects. Human Vaccines \& Immunotherapeutics, 16:12, 2913-2920, 2020. https://doi:10.1 080/21645515.2020.1842034.

[2] B. Shanmugaraj and W. Phoolcharoen, Addressing demand for recombinant biopharmaceuticals in the COVID-19 era. Asian Pacific Journal of Tropical Medicine, 14(2), 49-51, 2021. https://doi:10.4103/ 1995-7645.306736.

[3] A.B. Jena, , N. Kanungo, V. Nayak, G.B.N. Chainy and J. Dandapat, Catechin and curcumin interact with $\mathrm{S}$ protein of SARS CoV2 and ACE2 of human cell membrane: insights from computational studies. Scientific Reports, 11, 2043, 1-14, 2021. https://doi.org/10.1038/s41598-021-81462-7.

[4] S. Shinde and A. Thomas, Plant derived polyphenol Catechin as a potential antiviral drug against Covid-19. Pharmaceutical Resonance, 3(2), 58-62, 2021. https:// doi. org/10.1080/07391102.2020.1796810.

[5] M. J .I. Shohag, F. Z. Khan, L. Tang, Y. Wei, Z. He and X. Yang, COVID-19 Crisis: How Can Plant Biotechnology Help? Plants, 10, 352, 1-10, 2021. https://doi. org/ 10.3390/plants10020352.

[6] O. Sytar, M. Brestic, S. Hajihashemi, M. Skalicky, J. Kubě̌, L. Lamilla-Tamayo, U. Ibrahimova, S. Ibadullayeva and M. Landi, COVID-19 Prophylaxis Efforts Based on Natural Antiviral Plant Extracts and Their Compounds. Molecules, 26, 727, 1-19, 2021. https://doi.org/ 10.3390/ molecules26030727.

[7] T. Khan, M. A. Khan, K. Karam, N. Ullah, Z. U. R. Mashwani and A. Nadhman, Plant in vitro Culture
Technologies; A Promise Into Factories of Secondary Metabolites Against COVID-19. Frontiers in Plant Science, 12, 610194, 1-21, 2021. https://doi:10.3389/ fpls. 2021.610194

[8] A. Ferid, A. Mohammed, S.I. Khalivulla, M. Korivi and M.K.A.A. Razab, Plant cell and callus cultures as an alternative source of bioactive compounds with therapeutic potential against coronavirus disease (COVID-19). IOP Conference Series: Earth and Environmental Science, $596 \quad 012099.2020$. https://doi:10.1088/1755-1315/596/ 1/012 099.

[9] I. Jahan and A. Onay, Potentials of plant-based substance to inhabit and probable cure for the COVID19. Turkish Journal of Biology, 44, 228-24, 2020. https://doi:10.3906/ biy-2005-114.

[10] N. Mahmood, S.B. Nasir and K. Hefferon, Plant-Based Drugs and Vaccines for COVID-19. Vaccines, 9, 15, 116, 2021. https://doi.org/10.3390/vaccines9010015.

[11] K. Siriwattananon, S. Manopwisedjaroen, P. Kanjanasirirat, P. Budi Purwono, K. Rattanapisit, B. Shanmugaraj, D.R. Smith, S. Borwornpinyo, A. Thitithanyanont and W. Phoolcharoen, Development of Plant-Produced Recombinant ACE2-Fc Fusion Protein as a Potential Therapeutic Agent Against SARS-CoV2. Frontiers in Plant Science, 11, 604663, 1-12, 2021. https://doi:10.3389/fpls.2020.604663.

[12] M. I. Sohail, A. Siddiqui, E. Natasha and M. Karmran, Chapter 25: Phytomedicine and the COVID-19 pandemic. In R.A.Bhat, K.R. Hakeem,, M.A.Dervash (Eds.) Phytomedicine: A Treasure of Pharmacologically Active Products from Plants. 693708. 2021.

[13] S. Rosalez-Mendosa, V. A. Merquez-Escobar, O. Gonzales-Ortega, R. Nieto-Gomez and J.I. ArevaloVillalobos, What Does Plant-Based Vaccine Technology Offer to the Fight against COVID-19?. Vaccines, 8, 183, 1-19, 2020. https://doi:10.3390/vaccines8020183.

[14] T.M. Karpinsky, M. Ozarowski, A.S. Mrozikiewicz, H. Wolski and D. Wlodkowic, The 2020 race towards SARS-CoV-2 specific vaccines. Theranostics, 11 (4), 1690-1702, 2021. https://doi:10.7150/thno.53691.

[15] N. Şekeroğlu and S. Gezici, Koronavirüs Pandemisi ve Türkiye'nin Bazı Şifalı Bitkileri. Anadolu Kliniği Tıp Bilimleri Dergisi, 25 (Özel Say1 1), 163-182, 2020. https://doi:10.21673/anadoluklin.724210.

[16] D. Paraskevis, E. G. Kostaki, G. Magiorkinis, G. Panayiotakopoulos, G. Sourvinos and S. Tsiodras, Fullgenome evolutionary analysis of the novel corona virus (2019-nCoV) rejects the hypothesis of emergence as a result of a recent recombination event. Infection, Genetics and Evolution, 79, 104212, 1-4, 2020. https://doi.org/ 10.1016/ j.meegid.2020.104212.

[17] Y. C. Liu, R. L. Kuo and S. R. Shih, COVID-19: The first documented coronaviruspandemic in history. Biomedical Journal, 43, 328-333, 2020. https://doi.org/10.1016/j.bj. 2020.04.007.

[18] M. Letko, A. Marzi and V. Munster, Functional assessment of cell entry and receptor usage for SARS- 
CoV-2 and other lineage B betacoronaviruses. Nature Microbiology, 5, 562-569, 2020. https://doi.org/10.1038/ s41564-020-0688-y.

[19] W. Liu, M.J. Moore, N. Vassilleva, J. Sui, S.K. Wong, M.A. Berne, M. Somasundaran, J.L. Sullivan, K. Luzuriaga, T.C. Greenough, H.Choe and M. Farzan, Angiotensin-converting enzyme 2 is a functional receptor for the SARS coronavirus. Nature, 426, 450454, 2003. https://doi:10. 1038/nature02145.

[20] M. De Jesus, J. T. Gaza, H. Junio and R. Nellas, Molecular docking of secondary metabolites from Psidium guajava L. and Piper nigrum L. to Covid-19 associated receptors ACE2, Spike Protein RBD, and TMPRSS2. ChemRxiv. Preprint, 2020. https://doi.org/10.26434/ chemrxiv.12867350.v1.

[21] F. R. Bhuiyan, S. Howlader, T. Raihan and M. Hasan, Plants metabolites: Possibility of natural therapeutics against the COVID-19 pandemic, Frontiers in Medicine, 7, 444, 1-26, 2020. https://doi:10.3389/fmed.2020.00444.

[22] L. Liu, J. Y. Gao, W. Hu, X. Zhang, L. Guo, C. Liu, Y. Tang, C. Lang, F. Mou, Z. Yi, Q.Pei, K. Sun, J. Xiang and J. Xiao, Clinical characteristics of 51 patients discharged from hospital with COVID-19 in Chongqing, China. medRxiv The Preprint Server for Health Science,

2020. https://doi.org/10.1101/2020.02.20.20025536.

[23] X. Qin, S. Qiu, Y. Yuan, Y. Zong, Z. Tuo, J. Li and J. Liu, Clinical characteristics and treatment of patients infected with COVID-19 in Shishou, China. The Lancet Respiratory Medicine, 2020. Preprint. https://dx.doi.org/ 10.2139/ssrn.3541147.

[24] S. Sharma and N. Negi, Production and Challenges of Plant based Vaccines. Annals of the Romanian Society for Cell Biology, 25(1), 3625 - 3639, 2021.

[25] Z. LeBlanc, P. Waterhouse and J. Bally, Plant-Based Vaccines: The Way Ahead? Viruses, 13, 5, 2021. https://dx.doi.org/doi:10.3390/v13010005.

[26] D. A. Ullisch, C. A. Müller, S. Maibaum, J. Kirchhoff, A. Schiermeyer, S. Schillberg, J. L. Roberts, W. Treffenfeld and J. Büchs, Comprehensive characterization of two different Nicotiana tabacum cell lines leads to doubled GFP and HA protein production by media optimization. Journal of Bioscience and Bioengineering, 113(2), 242-248, 2012. https://doi:10.1016/j.jbiosc.2011.09.022.

[27] Z. He, X. Du, W. Yao and J. Dai, Pharmaceutical proteins produced in plant bioreactor in recent years. African Journal of Biotechnology, 7 (25), 4917-4925, 2008.

[28] K. Herbers and U. Sonnewald, Production of new/modified proteins in transgenic plants. Current Opinion in Biotechnology, 10, 163-168, 1999. https://doi:10.1016/ s0958-1669(99)80029-9.

[29] E. Altındiş, S. Gülçe-İz, M. Ö. Ozen, P. Nartop, İ. Deliloğlu-Gürhan and A. Gürel, Plant derived edible vaccines and therapeutics, Frontier in Clinical Drug Research: Anti-Infectives, Vol(1), 200-236, 2014.
[30] Y. C. Kuo, C. C. Tan, J. Y. Ku, W. C. Hsu, S. C. Su, C. A. Lu and L. F. Huang, Improving pharmaceutical protein production in Oryza sativa. International Journal of Molecular Science, 14, 8719-8739, 2013. https://doi: 10.3390/ijms14058719.

[31] B. R. Holtz, B. R. Berquist, L. D. Bennet, V. J. M. Kommineni, R. K. Munigunti, E. L. White, D. C. Wilkerson, K. Y. I. Wongii, L. H. Ly and S. Marcel, Commercial-scale biotherapeutics manufacturing facility for plant-made pharmaceuticals. Plant Biotechnology Journal, 13, 1180-1190, 2015. https://doi:10.1111/pbi.12469.

[32] A. K. Sharma and M. K. Sharma, Plants as bioreactors: Recent developments and emerging opportunities. Biotechnology Advances, 27, 811-832, 2009. https://doi.org/10.1016/j.biotechadv.2009.06.004.

[33] L .R. Wilken and Z. L. Nikolov, Recovery and purification of plant-made recombinant proteins. Biotechnology Advances, 30, 419-433, 2012. https://doi: 10.1016/j.biotechadv.2011.07.020.

[34] J. Xu, M. C. Dolan, G. Medrano, C. L. Cramer and P. J. Weathers, Green factory: Plants as bioproduction platforms for recombinant proteins. Biotechnology Advances, 30, 1171-1184, 2012. https://doi:10.1016/ j.biotechadv. 2011 . 08.020.

[35] M. M. Rigano and A. M. Walmsley, Expression systems and developments in plant-made vaccines. Immunology and Cell Biology, 83, 271-277, 2005. https://doi:10.1111/j.1440-1711.2005.01336.x.

[36] M. M. Rigano, G. D. Guzman, A. M. Walmsley, L. Frusciante and A. Barone, Production of pharmaceutical proteins in solanaceae food crops. International Journal of Molecular Science, 14, 2753 2773, 2013. https://doi:10.3390/ijms14022753.

[37] P. Rashmi and B. L. R. Madhavi, Vaccine development and delivery strategies-A glimpse. Journal of Vaccines and Immunology, 7(1), 004-008, 2021. https://dx.doi.org/ 10.17352/jvi.000038.

[38] Medicago, 2020. (Erişim tarihi: 20.03.2021) https://www.medicago.com/en/covid-19-programs/

[39] Covid19 Vaccine Tracker. (Erişim tarihi: 20.03.2021) https://covid19.trackvaccines.org/vaccines/18/

[40] K. A. McDonald and R. B. Holtz, From farm to finger prick-A perspective on how plants can help in the fight against COVID-19. Frontiers in Bioengineering and Biotechnology, 8, 782, 1-5, 2020. https://doi:10.3389/ fbioe.2020.00782.

[41] S. Nandi, A. T. Kwong, B. R. Holtz, R. L. Erwin, S. Marcel, and K. A. McDonald, Techno-economic analysis of a transient plantbased platform for monoclonal antibody production. mAbs, 8, 1456-1466, 2016. https://doi:10.1080/ 19420862.2016.1227901.

[42] Ortaakarsu, A. (Erişim tarihi: 24.03.2021). https://www.ortaakarsu.net/?cat=6

[43] N. Mohammadi and N. Shaghaghi, Inhibitory effect of eight secondary metabolites from conventional medicinal plants on COVID_19 virus protease by molecular docking analysis. ChemRxiv. Preprint, 2020. https://doi.org/ 10.26434/chemrxiv.11987475.v1 
[44] M. H. Abdellatiif, A. Ali, A. Ali and M. A. Hussien, Computational studies by molecular docking of some antiviral drugs with COVID-19 receptors are an approach to medication for COVID-19. Open Chemistry, $19, \quad 245-264, \quad 2021$. https://doi.org/10.1515/chem-2021-0024.

[45] R. Patil, R. Chikhale, P. Khanal, N. Gurav, M. Ayyanar, S. Sinha, S. Prasad, Y. N. Dey, M. Wanjari and S.S. Gurav, Computational and network pharmacology analysis of bioflavonoids as possible natural antiviral compounds in COVID-19. Informatics in Medicine Unlocked, 22, 100504, 1-14, 2021. https://doi.org/ 10.1016/j.imu.2020.100504.

[46] D. Kumar and S. Bhagat, Natural compound against COVID-19 in silico screening by attacking Mpro and ACE2 using molecular docking. International Journal for Research in Applied Sciences and Biotechnology, $7(6), \quad 168-180, \quad 2020$ https://doi.org/10.31033/ijrasb.7.6.25.

[47] H. M. Wahedi, S. Ahmad and S. W. Abbasi, Stilbenebased natural compounds as promising drug candidates against COVID-19. Journal of Biomolecular Structure and Dynamics, 1-10, 2020. https://doi.org/ 10.1080/07391102. 2020.1762743.

[48] P. Pandey, F. Khan, A. K. Rana, Y. Srivastava, S. K. Jha and N. K. Jha, A drug repurposing approach towards elucidating the potential of flavonoids as COVID-19 spike protein inhibitors. Biointerface Research in Applied Chemistry, 11(1), 8482 - 8501, 2021. https://doi.org/ 10.33263/BRIAC111.84828501.

[49] S. Kumar, P. Kashyap, S. Chowdhury, S. Kumar, A. Panwar and A. Kumar, Identification of phytochemicals as potential therapeutic agents that binds to Nsp15 protein target of coronavirus (SARS$\mathrm{CoV}-2)$ that are capable of inhibiting virus replication. Phytomedicine, In Press, 2021. https://doi.org/10.1016/j.phymed.2020.153317.

[50] R. Farjaminezhad and G. Garoosi, Improvement and prediction of secondary metabolites production under yeast extract elicitation of Azadirachta indica cell suspension culture using response surface methodology. AMB express, 11-43, 1-16, 2021. https://doi:10.1186/s13568-021-01203-x.

[51] A. Teke, M. Yener, Ş. Akkuş and A. Gümüşçü, Chapter 12: Halkın Tibbi-Aromatik Bitkiler Kullanımı Ve Tanımasında Bilinç Durumu: Çumra Örneği. Research in Medicinal and Aromatic Plants (Edt: Gülen Özyazıc1).Iksad Publication. 267:289. 2020.

[52] S. Mazraedoost, G. Behbudi, S. M. Mousavi and S. A. Hashemi, Covid-19 treatment by plant compounds. Advances in Applied NanoBio-Technologies, 2(1), 23 33, 2020. https://dx.doi.org/10.47277/AANBT/2(1)33.

[53] M. Srivastava and P. Misra, Enhancement of Medicinally Important Bioactive Compounds in Hairy Root Cultures of Glycyrrhiza, Rauwolfia, and Solanum Through In Vitro Stress Application. In: Malik S. (eds) Production of Plant Derived Natural Compounds through Hairy Root Culture. Springer, Cham. 2017. https://doi.org/10.1007/978-3-319-69769-7_6
[54] J. Cinatl, B. Morgenstern, G. Bauer, P. Chandra, H. Rabenau and H. W. Doerr, Glycyrrhizin, an active component of liquorice roots, and replication of SARSassociated coronavirus. The Lancet, 361, 2045-2046, 2003. https://doi:10.1016/s0140-6736(03)13615-x.

[55] J. K. Cho, M. J. Curtis-Long, K. H. Lee, D. W. Kim, H. W. Ryu, H. J. Yuk and K. H. Park, Geranylated flavonoids displaying SARS-CoV papain-like protease inhibition from the fruits of Paulownia tomentosa. Bioorganic \& Medicinal Chemistry, 21, 3051-3057, 2013. https://doi.org/10.1016/ j.bmc.2013.03.027.

[56] D. W. Kim, K. H. Seo, M. J. Curtis-Long, K. Y. Oh, J. W. Oh, J. K. Cho, K. H. Lee and K. H. Park, Phenolic phytochemical displaying SARS-CoV papain-like protease inhibition from the seeds of Psoralea corylifolia. Journal of Enzyme Inhibition and Medicinal Chemistry, 29(1), 59-63, 2014. https://doi.org/10.3109/14756366.2012.753591.

[57] Y. B. Ryu, H. J. Jeong, J. H. Kim, M. Y. Kim, J. Y. Park, D. Kim, T. T. H. Nguyen, S. J. Park, J. S. Chang, K. H. Park, M. C. Rho and W. S. Lee, Biflavonoids from Torreya nucifera displaying SARS-CoV 3CL (pro) inhibition. Bioorganic \& Medicinal Chemistry, 18(22), 7940-7947, 2010. https://doi.org/10.1016/j.bmc.2010.09.035.

[58] H. Liu, F. Ye, Q. Sun, H. Liang, C. Li, S. Li, R. Lu, B. Huang, W. Tan and L. Lai, Scutellaria baicalensis extract and baicalein inhibit replication of SARS-CoV2 and its 3C-like protease in vitro. Journal of Enzyme Inhibition and Medicinal Chemistry, 36(1), 497-503, 2021. 10.1080/14756366.2021.1873977.

[59] F. Chen, K. H. Chan, Y. Jiang, R. Y. T. Kao, H. T. Lu, K. W. Fan, V. C. C. Cheng, W. H. W. Tsui, I. F. N. Hung, T. S. W. Lee, Y. Guan, J. S. M. Peiris and K. Y. Yuen, In vitro susceptibility of 10 clinical isolates of SARS coronavirus to selected antiviral compounds. Journal of Clinical Virology, 31, 69-75, 2004. http://doi:10.1016/ j.jcv.2004.03.003.

[60] J. Y. Park, H. J. Yuk, H. W. Ryu, S. H. Lim, K. S. Kim and K. H. Park, Evaluation of polyphenols from Broussonetia papyrifera as coronavirus protease inhibitors. Journal of Enzyme Inhibition and Medicinal Chemistry, 32(1), 504-512, 2017. http://dx.doi.org/10.1080/14756366. 2016. 1265519.

[61] J. Y. Kim, Y. I. Kim, S. J. Park, I. K. Kim, Y. K. Choi and S. H. Kim, Safe, high-throughput screening of natural compounds of MERS-CoV entry inhibitors using a pseudovirus expressing MERS-CoV spike protein. International Journal of Antimicrobial Agents, 52, 730-732, 2018 . http://doi:10.1016/j.ijantimicag.2018.05.003.

[62] T. Y. Ho, S. L. Wu, J. C. Chen, C. C. Li and C. Y. Hsiang, Emodin blocks the SARS coronavirus spike protein and angiotensin-converting enzyme 2 interaction. Antiviral Research, 74, 92-101, 2007. https://doi.org/10.1016/ j .antiviral.2006.04.014.

[63] C. Y. Wu, J. T. Jan, S. H. Ma, C. J. Kuo, H. F. Juan, Y. S. E. Cheng, H. H. Hsu, H. C. Huang, D. Wu, A. Brik, 
F. S. Liang, R. S. Liu, J. M. Fang, S. T. Chen, P. H. Liang and C. H. Wong, Small molecules targeting severe acute respiratory syndrome human coronavirus. Proceedings of the National Academy of Sciences of the United States of America, 101(27), 10012-10017, 2004. https://doi:10.1073/ pnas.0403596101.

[64] T. T. H. Nguyen, H. J. Woo, H. K. Kang, V. D. Nguyen, Y. M. Kim, D. W. Kim, S. A. Ahn, Y. Xia and D. Kim, Flavonoid-mediated inhibition of SARS coronavirus 3C-like protease expressed in Pichia pastoris. Biotechnology Letters, 34, 831-838, 2012. https://doi.org/ 10.1007/s10529-011-0845-8.

[65] C. W. Lin, F. J. Tsai, C. H. Tsai, C. C. Lai, L. Wan, T. Y. Ho, C. C. Hsieh and P. D. L. Chao, Anti-SARS coronavirus 3C-like protease effects of Isatis indigotica root and plant-derived phenolic compounds. Antiviral Research, 68, 36-42, 2005. https://doi.org/10.1016/j.antiviral .2005.07.002.

[66] J. Y. Park, H. J. Jeong, J. H. Kim, Y. M. Kim, S. J. Park, D. Kim, K. H. Park, W. S. Lee and Y. B. Ryu, Diarylheptanoids from Alnus japonica inhibit papainlike protease of severe acute respiratory syndrome coronavirus. Biological and Pharmaceutical Bulletin, 35(11), 2036-2042, 2012. https://doi.org/10.1248/bpb.b12-00623.

[67] Y. B. Ryu, S. J. Park, Y. M. Kim, J. Y. Lee, W. D. Seo, J. S. Chang, K. H. Park, M. C. Rho and W. S. Lee, SARS-CoV 3CLpro inhibitory effects of quinonemethide triterpenes from Tripterygium regelii. Bioorganic \& Medicinal Chemistry Letters, 20, 1873 1876, 2010. https://doi:10.1016/j.bmcl.2010.01.152.

[68] K. H. Chiow, M. C. Phoon, T. Putti, B. K. H. Tan and V. T. Chow, Evaluation of antiviral activities of Houttuynia cordata Thunb. extract, quercetin, quercetrin and cinanserin on murine coronavirus and dengue virus infection. Asian Pacific Journal of Tropical Medicine, 9(1), 1-7, 2016. http://dx.doi.org/10.1016/j.apjtm.2015.12.002.

[69] J. Y. Park, J. A. Ko, D. W. Kim, Y. M. Kim, H. J. Kwon, H. J. Jeong, C. Y. Kim, K. H. Park, W. S. Lee and Y. B. Ryu, Chalcones isolated from Angelica keiskei inhibit cysteine proteases of SARS-CoV. Journal of Enzyme Inhibition and Medicinal Chemistry, $\quad 31(1), \quad 23-30, \quad 2016$. https://doi.org/10.3109/14756366.2014.1003215.

[70] H. H. Fan, L. Q. Wang, W. L. Liu, X. P. An, Z. D. Liu, X.Q. He, L. H. Song and Y. G. Tong, Repurposing of clinically approved drugs for treatment of coronavirus disease 2019 in a 2019-novel coronavirus-related coronavirus model. Chinese Medical Journal, 133(9), 1051-1056, 2020. https://doi:10.1097/CM9.0000000000000797.

[71] Y. C. Tsai, C. L. Lee, H. R. Yen, Y. S. Chang, Y. P. Lin, S. H. Huang and C. W. Lin, Antiviral action of tryptanthrin isolated from Strobilanthes cusia leaf against Human Coronavirus NL63. Biomolecules, 10 (366), 1-17, 2020. https://doi:10.3390/biom10030366.

[72] M. Hesami and A. M. P. Jones, Application of artificial intelligence models and optimization algorithms in plant cell and tissue culture. Applied Microbiology and Biotechnology, 104, 9449-9485, 2020. https://doi.org/ 10.1007/s00253-020-10888-2.

[73] N. Nabi, S. Singh and P. Saffeullah, Responses of in vitro cell cultures to elicitation: regulatory role of jasmonic acid and methyl jasmonate: a review. In Vitro Cellular \& Developmental Biology-Plant, 57, 341-355, 2021. https://doi.org/10.1007/s11627-020-10140-6. 